\title{
The Barriers to Corporate Social Responsibility in the Nordic Energy Sector
}

\author{
Mauricio Latapí ${ }^{1, *(\mathbb{D})}$, Lára Jóhannsdóttir ${ }^{1}{ }^{\mathbb{C}}$, Brynhildur Davíðsdóttir $^{1}$ and Mette Morsing ${ }^{2}$ \\ 1 Environment and Natural Resources Program, University of Iceland, 102 Reykjavík, Iceland; \\ laraj@hi.is (L.J.); bdavids@hi.is (B.D.) \\ 2 Department of Management, Society, and Communication, Copenhagen Business School, \\ DK 2000 Copenhagen, Denmark; morsing@unglobalcompact.org \\ * Correspondence: mal25@hi.is
}

Citation: Latapí, M.; Jóhannsdóttir, L.; Davíðsdóttir, B.; Morsing, M. The Barriers to Corporate Social Responsibility in the Nordic Energy Sector. Sustainability 2021, 13, 4891. https://doi.org/10.3390/su13094891

Academic Editor: Andrea Pérez

Received: 2 April 2021

Accepted: 22 April 2021

Published: 27 April 2021

Publisher's Note: MDPI stays neutral with regard to jurisdictional claims in published maps and institutional affiliations.

Copyright: (c) 2021 by the authors. Licensee MDPI, Basel, Switzerland. This article is an open access article distributed under the terms and conditions of the Creative Commons Attribution (CC BY) license (https:/ / creativecommons.org/licenses/by/ $4.0 /)$.

\begin{abstract}
Nordic companies have been at the top of sustainable business rankings since the early 2010s. Some of them are energy companies that have adopted Corporate Social Responsibility to have a positive social impact and become carbon neutral. However, limited literature has analyzed the barriers that Nordic energy companies face while implementing Corporate Social Responsibility. This article aims to identify and categorize the barriers faced by Nordic energy companies. The research is based on empirical data obtained from interviews involving high-level managers from the largest suppliers of energy in the Nordic region. A model is developed, which identifies and categorizes seven barriers at the individual level, seven at the organizational level, and three at the institutional level of analysis. The findings suggest that barriers can be of a direct and indirect nature and can be found across the three levels of analysis. The main contributions of this article are: (1) it identifies and categorizes the barriers that Nordic energy companies face; (2) it defines the barriers as direct and indirect based on their interaction with the company; (3) it presents two models of the barriers and provides empirical evidence that complement the literature; and (4) it contributes to the literature by focusing on the Nordic countries, a region that has received limited attention by scholarly research.
\end{abstract}

Keywords: Corporate Social Responsibility; barrier; energy; Nordic; sustainability; strategy; sustainable development; business models

\section{Introduction}

Since the early 2010s, Nordic companies have been at the top of business rankings (e.g., [1,2]) and are considered as some of the most sustainable in the world. Notably, some of them are energy companies that have implemented Corporate Social Responsibility (CSR) as a business model that can help them address the Sustainable Development Goals (SDGs) and become carbon-neutral in the long term. The adoption of CSR by energy companies is of great significance considering that the sustainable development of the energy sector and its transition towards renewable sources has a direct and indirect influence on achieving most of the SDGs [3,4]. However, limited literature has analyzed the barriers that energy companies face in the implementation of CSR.

While the barriers to CSR implementation have been analyzed through different perspectives such as the size of the organization [5,6], the national or regional context [7-9], and the industry where they operate $[10,11]$, the topic has not been covered in a thorough manner by academic literature [12]. Additionally, empirical studies on the barriers to CSR have focused on specific regions and countries such as Spain (see [13]), Saudi Arabia (see [7]), India (see [9]), and Greece (see [14]), while other studies have looked at the barriers from specific perspectives such as human resource management (see [15]) and human resource development (see [16]). Furthermore, a comprehensive study of the specific barriers faced by energy companies seems to be missing. A study focused on the Nordic region is of relevance considering that Nordic countries are recognized as leaders 
in sustainability and frontrunners in the incorporation of renewable energy sources into their energy markets [17]. For this research, Nordic companies are considered those with headquarters and operations in the Nordic countries (Denmark, Finland, Iceland, Norway, and Sweden). By 2018, the overall share of renewables in the energy supply in the Nordic region was $40 \%$, while it was only $15 \%$ for the EU27 (the 27 countries that form the European Union) [18]. While the Nordic energy market is considered an energy-only market (as opposed to a capacity market), the Nordic countries have been able to incorporate renewables in a way that guarantees the balance between supply and demand in a flexible manner [19] (The Nordic West Office explains the difference between energy-only market and capacity market in the following way: "In an energy-only market, a price is paid for energy produced rather than for keeping capacity ready, although some complementary mechanisms exist to guarantee a balance between supply and demand" [19] (p. 17).) Additionally, the five Nordic countries have set the goal to completely decarbonize their energy systems by 2050 at the latest [20] and to be the most sustainable region in the world by 2030 [21]. In specific, Iceland aims to achieve carbon neutrality in 2040, and Norway aims to achieve climate neutrality in 2030, while Finland aims to achieve zero net emissions in 2035, Sweden in 2045, and Denmark in 2050 [22].

Additionally, in decade of 2010 to 2020, Nordic companies have been considered leaders in the implementation of sustainable business models and have been at the top of sustainability rankings (e.g., [1,2]). Notably, Corporate Knights [1] has ranked two Nordic energy companies in the top three most sustainable companies in the world for the rankings for the year 2020 (\#1 Orsted and \#3 Neste, both included in this study). Another aspect is that Nordic countries can be considered developed economies and have some of the highest living standards, while at the same time they have some of the highest energy consumption per capita in Europe as a result of their energy-intensive industries and their sparsely populated areas [17]. However, Nordic countries have been steadily reducing the $\mathrm{CO}_{2}$ intensity of their total primary energy demand, and since 2015 have been below the average of the members of the Organisation for Economic Co-operation and Development (OECD) [18].

This context represents a significant opportunity to conduct empirical research that can provide a better understanding of Nordic energy companies and the barriers they face in the implementation of CSR. An empirical study of this kind would help fill in the gap in the literature by covering aspects that are missing with regards to the barriers to CSR implementation and could provide evidence that complements existing studies on the topic. With this in mind, the overall aim of this study is to identify and categorize the barriers faced by Nordic energy companies. To do so, this research intends to answer the following questions:

Which barriers do Nordic energy companies face in the implementation of Corporate Social Responsibility?

How do the barriers faced by Nordic energy companies influence the implementation of "implicit" and "explicit" Corporate Social Responsibility?

The novelty of this research resides in providing empirical evidence of the barriers to CSR implementation in the Nordic energy sector. To begin with, the region has received a low level of attention from the literature focused on CSR in the energy sector. According to Latapí Agudelo et al. [23], only 12\% of the academic publications focused on this topic have revolved around Nordic countries. Furthermore, only a limited number of empirical studies have identified the barriers to CSR with a particular focus on Nordic companies. For example, Ditlev-Simonsen [24] focused on employee perception, attitude, and engagement in CSR in the Nordic context, while Johannsdottir et al. [25] analyzed talent management and CSR in the Nordic insurance sector. To the best of our knowledge, no academic studies have focused on the barriers to CSR specifically for the Nordic energy sector, making this an original research that is both timely and relevant.

This research was based on semi-structured interviews with high-level managers from Nordic energy companies, which resulted in three key findings: (1) Nordic energy 
companies face a diversity of barriers to implement CSR at the individual, organizational, and institutional level; (2) identification and categorization of seven barriers at the individual level, seven at the organizational level, and three at the institutional level; and (3) Nordic energy companies face direct and indirect barriers across the three levels of analysis depending on their interaction with the company.

This article contributes to the literature on the barriers to CSR implementation by proposing two models to provide an innovative and holistic perspective of the barriers that Nordic energy companies face. The identification and categorization provided by this research can contribute to the understanding of the barriers to CSR. This is particularly relevant in the current context of climate change and the SDGs considering that the energy sector has a direct and indirect influence in achieving the rest of the goals [3].

The paper adopts the following structure: the introduction (Section 1) is followed by Section 2, which provides the literature review and theoretical framework for this research. Then, Section 3 presents the theoretical framework and is followed by Section 4 which presents the research method in a thorough way that explains all the steps followed in conducting the research, as well as details of the selection criteria and the participants. Afterward, Section 5 presents the findings beginning with an overview of the interviews and their characteristics. This is followed by the identification and categorization of the barriers at the individual, organizational, and institutional levels. Then, the discussion is presented in Section 6 to provide the analysis of the findings, as well as the models proposed by this article. Finally, Section 7 presents the conclusions of the paper along with its implications, limitations, and a reflection on the opportunities for future research.

\section{Literature Review}

This section provides the background and literature review for the research.

\subsection{Corporate Social Responsibility}

The history and evolution of CSR can be traced back several centuries [26]. However, it was not until the 1930s and 1940s when the social responsibilities of corporations were first discussed in the literature and, as a result, began the debate around the modern definition of CSR as a conceptual paradigm $[27,28]$. Since then, CSR has evolved from rarely being addressed in business and management-oriented publications to being widely discussed and acknowledged by the academic, private, and public sectors [27].

The evolution of the modern understanding of CSR during the 20th and 21st centuries has resulted in many definitions of the concept in academic and non-academic literature (see [27-29]). However, this research follows the understanding and definition of CSR proposed by the European Commission [30], considering that it has been a fundamental element of the European Strategy for CSR. The definition brought forward by the European Commission [30] indicates that all companies are responsible for their social and environmental impact, and to be responsible, they need to incorporate "social, environmental, ethical human rights and consumer concerns into their business operations and core strategy" [30] (p. 4). This definition of CSR acknowledges that companies are responsible for their social and environmental impact and indicates that they should integrate societal expectations of corporate behavior into their business models. As a result, this conceptualization of CSR moves the approach to responsible corporate behavior from a limited shareholder perspective (see [31]) to a holistic perspective that considers all stakeholders (see [32,33]).

The European Commission [34] further advanced its conceptualization of CSR in 2015 by indicating additional considerations for the European Strategy for CSR. The most significant aspects include:

In the European context, the term "Corporate Social Responsibility (CSR) is used as a synonym to reference 'sustainability', 'responsible business conduct' or 'business and human rights'” [34] (p. 1). 
The integration of "social, environmental, ethical human rights and consumer concerns into their business operations and core strategy" [30] (p. 4) must be done in close cooperation with the company's stakeholders.

Companies should pay particular attention to human rights and ethical considerations in line with the United Nations Guiding Principles on Business and Human Rights.

While there are competing and alternative concepts to CSR, such as stakeholder theory (e.g., [32,33]), corporate citizenship (e.g., [35,36]), and corporate sustainability (e.g., [37,38]), this research considers Carroll's [39] belief that all of them are interrelated and overlapping, and have been incorporated into the modern understanding of CSR. With this in mind, this study considers that responsible business models, regardless of their name, fall under the modern understanding and conceptualization of CSR.

\subsection{CSR in the Energy Sector}

The findings of Latapí Agudelo, Johannsdottir, and Davidsdottir [23] suggest that the implementation of CSR in the energy sector has not been analyzed as much, considering that with their review, they found that from 1990 to 2018 only fifty-five academic articles were published with a focus on CSR in the energy sector. Furthermore, Latapí Agudelo, Johannsdottir, and Davidsdottir [23] identified only twelve publications focused specifically on CSR implementation in the energy sector. The findings from those twelve publications suggest the following: CSR implementation responds to the institutional context where the company operates [40-44]; some energy companies see CSR as a tool for legitimizing their activities [45,46]; company-specific aspects, such as leadership and employees, play a significant role in the effective implementation of CSR [47,48]; each energy company has specific motivations and a unique approach to CSR implementation [49]; and CSR can be used by energy companies as a way for advancing their efforts for becoming sustainable, as well as for transitioning towards renewable sources [50,51].

Studying and understanding the approach of energy companies to CSR is particularly significant considering that the energy sector has a direct and indirect influence in achieving most of the SDGs [4,52]. Furthermore, the approach of energy companies to CSR can be expected to play a crucial role in achieving Sustainable Development Goal number 7 (SDG7), which aims to "ensure access to affordable, reliable, sustainable and modern energy for all" [3] (para. 1). Addressing SDG7 is particularly relevant because it is considered as an enabling factor for achieving the rest of the SDGs, in particular goals 6, 8, 9, 11, 12, and 13 [4]. Beyond that, CSR can be expected to play a significant role in the current energy transformation, considering that the International Renewable Energy Agency (IRENA) expects it to change the way the energy sector operates, resulting in "[environmental], social, economic and political implications" [53] (p. 14). With this in mind, it is relevant to understand the barriers for energy companies to implementing CSR.

\subsection{Barriers to CSR}

Companies are goal-oriented complex social systems that are driven towards responsible corporate behavior by a variety of factors [54]. However, in their efforts to implement CSR, firms face barriers that can limit their capability to be responsible. Scholars have defined the barriers to CSR as those internal and external factors that prevent companies from fully engaging in CSR and hinder its effective implementation (see [55-57]). The barriers have been analyzed at the individual, organizational, and institutional levels from different perspectives based on the size, context, and industry where the company operates.

\subsection{Barriers at the Individual Level}

Even when companies are goal-oriented and complex social structures [54], they consist of people and their relationships and interactions with one another [58]. Studies on the micro-foundations of CSR explain that individuals within a company have a relevant influence on CSR implementation through factors such as motivation, performance, attitude, and psychological processes $[59,60]$, as well as individual beliefs and values, 
pressure from external stakeholders, and level of independence within the firm [61-63]. The scholars focused on the micro-foundations of CSR also explain that the ways in which employees perceive, interpret, and assimilate CSR can be reflected in their attitude and work behavior towards CSR [60], and explain that individuals tend to give more attention and relevance to negative information and negative aspects of corporate behavior [64]. This means that factors at the individual level of analysis can have a significant influence on the effective implementation of CSR. As a result, individuals within a company at all levels, from the leadership to the bottom of the hierarchical structure of the firm, can have a direct and indirect influence in the way CSR is implemented. (This research considers that all individuals within a company have a certain influence on the effective implementation of CSR. Leaders and managers are expected to guide and drive forward CSR and require the support of middle and lower management within the firm. Employees that are not part of the management structure play a significant role in the overall perception of safety, wellbeing, and satisfaction, which in turn influences the work habits and attitude of the rest of the employees. These considerations are based on [58-62,64]). This means that factors at the individual level can become barriers to CSR implementation [16,58]. For instance, employees can develop negative work habits and a negative attitude toward the company's CSR as a result of a variety of factors related to individual perceptions of safety, wellbeing, and overall satisfaction with the organization [57]. Additional factors that affect individuals within a company and limit the effective implementation of CSR have been identified in the literature as those aspects that are directly linked to psychological, behavioral, attention, and focus aspects $[16,59,65]$. These factors can influence individual behavior within an organization and can hinder the implementation of CSR. Based on these considerations, seven barriers to CSR can be identified in the literature (see Table 1):

Table 1. Barriers at the individual level.

\begin{tabular}{|c|c|c|}
\hline Barrier & Description & Theoretical Support \\
\hline $\begin{array}{l}\text { Company's negative } \\
\text { contribution to society }\end{array}$ & $\begin{array}{l}\text { Individual employees perceive that the company does not make a } \\
\text { just and positive contribution to society. As a result, individuals } \\
\text { within the firm modify their attitude towards the company's CSR, } \\
\text { resulting in their limited involvement and support towards it. }\end{array}$ & {$[12,16,66,67]$} \\
\hline $\begin{array}{l}\text { Decision-making based } \\
\text { on egocentrism }\end{array}$ & $\begin{array}{l}\text { Decision-making within the company is made based on individual } \\
\text { judgments of what is fair or right. Individual factors such as greed, } \\
\text { corruption, and lack of moral values guide individual decisions that } \\
\text { have implications for the organization. }\end{array}$ & {$[8,14,16,68]$} \\
\hline $\begin{array}{l}\text { Lack of CSR fit, motivation, } \\
\text { and commitment }\end{array}$ & $\begin{array}{l}\text { Individuals within the company believe that CSR does not fit with } \\
\text { the organization's strategy and corporate values. This results in an } \\
\text { individual lack of motivation for implementing CSR, as well as a } \\
\text { lower level of commitment towards it. }\end{array}$ & {$[15,16,57,65,69]$} \\
\hline & $\begin{array}{l}\text { Individuals within the company have limited knowledge and } \\
\text { understanding of CSR. }\end{array}$ & \\
\hline $\begin{array}{l}\text { Lack of CSR knowledge } \\
\text { and awareness }\end{array}$ & $\begin{array}{l}\text { Additionally, individual decision-makers have limited involvement } \\
\text { in the company's CSR. As a result, individuals frequently find it } \\
\text { difficult to learn more about such activities and become involved and } \\
\text { committed to the company's CSR. }\end{array}$ & {$[7-9,14,16,55,65,70-73]$} \\
\hline Lack of CSR leadership & $\begin{array}{l}\text { Individuals in the leadership and top management do not support } \\
\text { the CSR agenda within the company. The individual leaders do not } \\
\text { drive forward CSR within the company, and as a result, it limits its } \\
\text { effective implementation. }\end{array}$ & {$[9-11,15,57,70,72,74]$} \\
\hline Lack of organizational support & $\begin{array}{l}\text { Individual decision-makers perceive a lack of organizational support. } \\
\text { This can result in lowering their focus and motivation to drive } \\
\text { forward the CSR agenda of the company. }\end{array}$ & {$[7,9,10,16,58,70]$} \\
\hline Negative attitude toward CSR & $\begin{array}{l}\text { Individuals within the company can have a negative attitude toward } \\
\text { CSR. This results in the failure to perceive the benefits of CSR, which } \\
\text { in turn leads individual employees to not fully support the } \\
\text { company's CSR. }\end{array}$ & {$[8,9,12,16,55,56]$} \\
\hline
\end{tabular}




\subsection{Barriers at the Organizational Level}

At the organizational level, the barriers to CSR can be defined as those factors that are linked to a company's structure and internal organizational systems and include aspects such as corporate values and culture, reward systems, internal structures, organizational inertia, and interaction between departments and employees [16]. As a result, barriers at the organizational level can limit the integration of CSR into the organizational structure and its core business $[10,70]$. Based on these considerations, seven barriers at the organizational level can be identified in the literature (see Table 2):

Table 2. Barriers at the organizational level.

\begin{tabular}{|c|c|c|}
\hline Barrier & Description & Theoretical Support \\
\hline $\begin{array}{l}\text { Lack of flexibility } \\
\text { and adaptability }\end{array}$ & $\begin{array}{l}\text { The company tends to resist change. } \\
\text { The organization is not flexible and able to adapt to changing } \\
\text { circumstances. } \\
\text { The flexibility and adaptability of the organization is usually } \\
\text { limited by routines, resource limitations, and structural power } \\
\text { struggles within the company. }\end{array}$ & {$[16,25,68,70,75]$} \\
\hline $\begin{array}{l}\text { Lack of integration of CSR to the } \\
\text { core business }\end{array}$ & $\begin{array}{l}\text { CSR is not fully integrated into the core business of the } \\
\text { organization. This limits the effectiveness of CSR for the company. } \\
\text { The company lacks transparency and accountability in relation to }\end{array}$ & {$[7,10,57,70,76]$} \\
\hline Lack of organizational trust & $\begin{array}{l}\text { its procurement process, as well as with relations with internal } \\
\text { and external stakeholders. As a result, there is a lack of trust in } \\
\text { the company to deliver what they promise in relation to CSR. }\end{array}$ & {$[5,13,55,75,77]$} \\
\hline $\begin{array}{l}\text { Lack of understanding of } \\
\text { the context }\end{array}$ & $\begin{array}{l}\text { The organization lacks the knowledge or capacity to implement } \\
\text { CSR with a holistic approach that goes beyond its areas of } \\
\text { operation and in accordance with the context where it operates. } \\
\text { The company lacks the strategic capacity to fully understand how } \\
\text { to implement CSR in a way that addresses aspects related to its } \\
\text { supply chain, regulations, procedures, and standards, as well as } \\
\text { in relation to cultural and social aspects. }\end{array}$ & {$[5,7]$} \\
\hline Limited access to resources & $\begin{array}{l}\text { The company has limited access to resources such as financial } \\
\text { resources, human capital, and access to market opportunities. } \\
\text { This limits its ability to implement CSR. }\end{array}$ & {$[5,6,9-11,14,15,55,70,72-74]$} \\
\hline $\begin{array}{l}\text { Misalignment of the } \\
\text { corporate culture }\end{array}$ & $\begin{array}{l}\text { The corporate culture in the company is not aligned with its CSR. } \\
\text { This limits the ability of CSR to guide the identity, purpose, and } \\
\text { direction of the company. }\end{array}$ & {$[14,57,72,78]$} \\
\hline Unfit organizational structure & $\begin{array}{l}\text { The organization has certain roles and responsibilities, as well as } \\
\text { patterns of interaction between individuals and authority levels, } \\
\text { that can limit the company's capability to implement CSR. } \\
\text { This includes the limited capability of the firm to establish } \\
\text { internal structures to ensure the compliance of CSR as the } \\
\text { company grows in size with new internal departments } \\
\text { and suppliers. }\end{array}$ & {$[5,15,16,55,68,74]$} \\
\hline
\end{tabular}

Synthesized from the literature.

\subsection{Barriers at the Institutional Level}

Institutional theory indicates that organizational behavior can only be understood within the societal and institutional context where a company operates, and as such, organizational behavior is constrained by its institutional context [79]. Institutional theory considers institutions as "supraorganizational patterns of activity through which humans conduct their material life in time and space, and symbolic systems through which they categorize that activity and infuse it with meaning" [79] (p. 232). This suggests that each institutional context is unique and has specific characteristics that influence organizational behavior. For instance, Scott [80] explains that an institutional context is defined by three pillars: regulatory, based on the belief that institutions limit and regularize behavior, while they also function as enablers of social systems; normative, based on the notion that institutions are influenced by the prevailing belief system and accepted set of norms that are 
either internalized or imposed; and cognitive, which considers how the social context is institutionalized. Then, it is possible to argue that the institutional context where a company operates can limit the effective implementation of CSR through cognitive, normative, and regulatory barriers (see Table 3).

Table 3. Barriers at the institutional level.

\begin{tabular}{|c|c|c|}
\hline Barrier & Description & Theoretical Support \\
\hline Cognitive barriers & $\begin{array}{l}\text { The institutional context where a company operates is influenced by } \\
\text { a shared belief system that prevails. This can negatively influence the } \\
\text { adoption and implementation of CSR based on a common perception } \\
\text { of corporate behavior. }\end{array}$ & {$[5,14,56,57,70,72,81]$} \\
\hline Normative barriers & $\begin{array}{l}\text { The institutional context is greatly influenced by the belief system } \\
\text { and accepted set of norms that prevails. This can influence individual } \\
\text { decision-makers within the organization, as they are exposed to } \\
\text { certain education and training activities, as well as to local and global } \\
\text { standards based on their networks, educational background, and } \\
\text { demography. } \\
\text { They are also influenced by operating in a specific industry that } \\
\text { follows certain standards, operating procedures, and criteria. As a } \\
\text { result, the normative context can negatively influence the adoption } \\
\text { and implementation of CSR. }\end{array}$ & {$[14,16,73,74,81,82]$} \\
\hline Regulatory barriers & $\begin{array}{l}\text { Corporate behavior is greatly influenced by the political context, } \\
\text { along with legislations and regulations, as well as compliance and } \\
\text { enforcement aspects. This influence can limit the company's capacity } \\
\text { to operate in congruence with what it considers to be responsible and } \\
\text { can limit the effective implementation of its CSR. }\end{array}$ & {$[5,10,14,55,57,70,72,73,82]$} \\
\hline
\end{tabular}

Synthesized from the literature.

\section{Theoretical Framework}

This research follows the notions of institutional theory, which explains that organizational behavior can only be understood by considering the social context where a company operates [79] and that each context has central institutions that influence organizational behavior [83]. Furthermore, this study considers the work of DiMaggio and Powell [84], which indicates that organizations face institutional isomorphic changes that can be of a coercive, mimetic, or normative character, and could help explain the barriers to CSR implementation.

As a theoretical foundation, this research builds on the comparative framework of CSR proposed by Matten and Moon [85] that defines "implicit" and "explicit" CSR as two ways in which companies approach responsible corporate behavior. For Matten and Moon [85], "implicit" CSR refers to the values, norms, and rules that motivate companies to address the expectations of their stakeholders through a collective perspective instead of an individual one, while "explicit" CSR refers to the corporate policies that assume responsibility based on the interests of society. Matten and Moon [85] explain that the motivations for "implicit" CSR come from the "societal consensus on the legitimate expectations of the roles and contributions of all major groups in society, including corporations", while the motivations for "explicit" CSR are the result from the opportunities that arise from "the perceived expectations of different stakeholders of the corporation" [85]. The framework of "implicit" and "explicit" CSR proposed by Matten and Moon [85] is of relevance for this research because it is grounded on institutional theory to explain that CSR is implemented in different ways depending on the context where a company operates.

Several frameworks can be used for the categorization of the barriers to CSR (e.g., [56,70,86]). For this study, the framework of Garavan, Heraty, Rock and Dalton [16], with their categorization of the barriers as individual, organizational, and institutional, seems the most suitable and was used as the basis for the analysis. The work of Garavan, Heraty, Rock, and Dalton [16] is particularly significant for this study because it provides an analysis of the barriers to CSR at three different levels (individual, organizational, and 
institutional) when most frameworks in the literature tend to focus on the organizational or the institutional level of analysis $[59,87]$ and approach the barriers to CSR from a specific perspective (e.g., the studies of Laudal [5] and Sweeney [6] revolve around the size of the company; the work of Pinto and Allui [57] and Skouloudis, Evangelinos, Nikolaou, and Filho [14] focus on the barriers in specific countries; and the publications of Alotaibi and Edum-Fotwe [7] and Yuen and Kim [10] center on specific industries).

Based on their findings, Garavan, Heraty, Rock, and Dalton [16] categorized the barriers to CSR implementation in the following way: (a) at the individual level of analysis, the barriers are those related to psychological, behavioral, and focus aspects that affect individual decision-makers; (b) at the organizational level of analysis, the barriers are structural and originate in organizational aspects such as corporate culture, organizational reward system, organizational inertia, and interactions between individuals; and (c) at the institutional level, the barriers go beyond individual organizations and include aspects at a macro level, such as rules and regulations, mimetic organizational tendencies, and a certain belief and values system at an institutional level. However, this study uses the work of Garavan, Heraty, Rock, and Dalton [16] as a starting reference and differs from it by approaching the analysis through CSR theory and by using empirical data to identify and categorize the barriers to CSR implementation in the Nordic energy sector.

\section{Research Method}

It is relevant to point out that this article was part of a broader research on Nordic energy companies which resulted in two academic articles from the same data-collection process. While both articles were based on the same data-collection process, their focus and analysis were different, and each one presents distinct and original empirical evidence. The first article called "The energy company of the Future: Drivers and characteristics for a responsible business framework" was published in 2021 and focused on identifying and categorizing the drivers for CSR implementation in the Nordic energy sector, as well as providing a definition for the energy company of the future from a CSR perspective.

This research was based on interviews conducted with high-level managers from different energy companies in the Nordic region. An interview framework was designed based on Rosenthal's [88] seven phases for conducting in-depth interviews: question design, selection criteria and sampling, interview modality, conducting the interviews, transcription, data analysis, and discussion of the research findings. The process followed for the research method is described in Figure 1.

\subsection{Interview Framework}

This section provides an explanation of each phase of the interview framework and the steps followed during the data collection.

\subsubsection{Question Design}

The interview framework followed a semi-structured design with open-ended and neutral questions that centered on one topic at a time (based on $[88,89])$. The questions were ordered coherently and progressively, which allowed the interviewer to guide the conversation (based on $[88,89]$ ). The questions were designed based on the literature on the barriers to CSR and focused on asking the interviewees which barriers they perceived at the individual, organizational, and institutional levels. The questions were asked in two stages: during the first stage, the questions focused on the barriers faced by their company, while the second stage focused on the barriers faced by Nordic energy companies in general. 


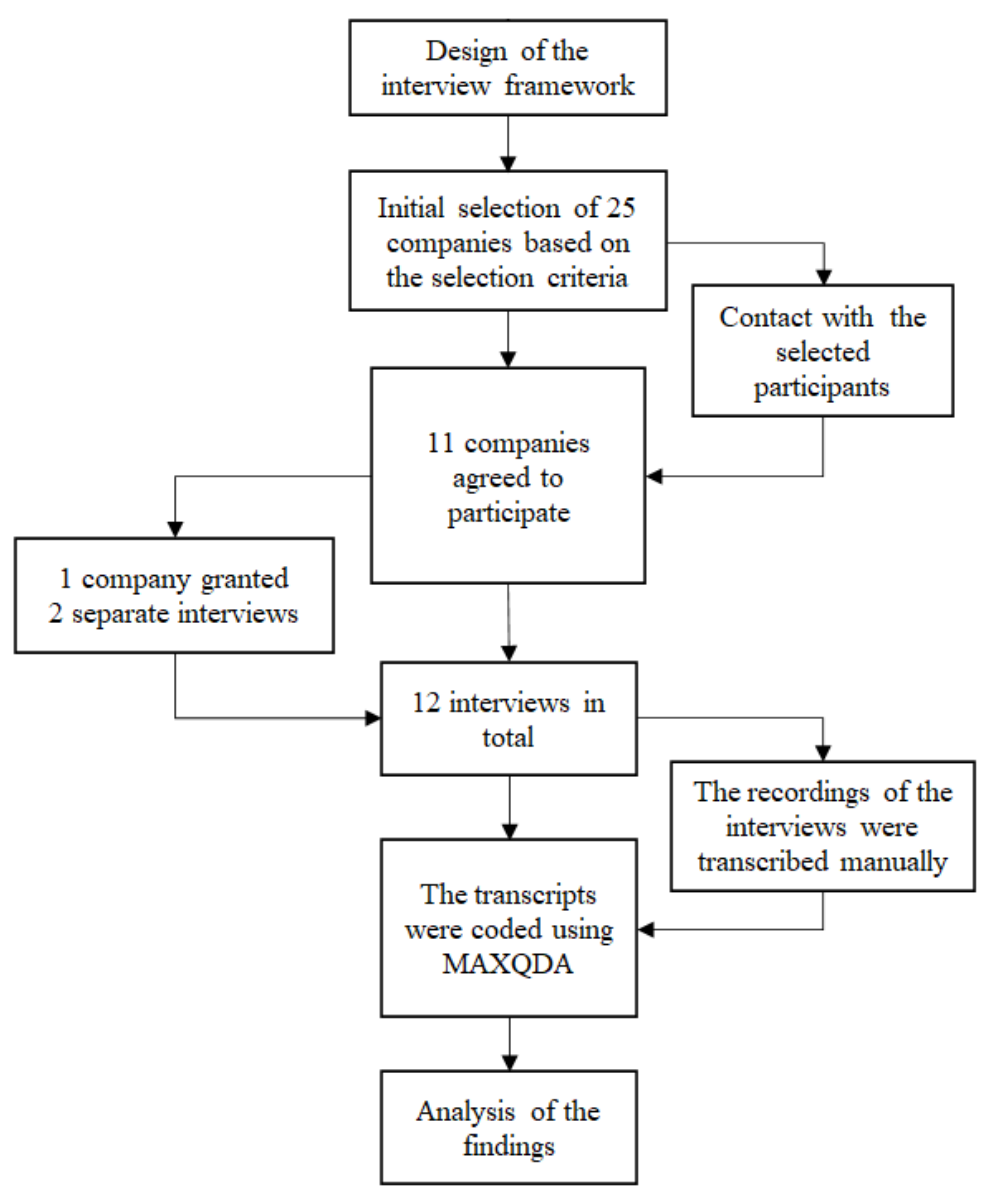

Figure 1. Research method process.

\subsubsection{Selection Criteria and Sampling}

The initial selection of participants was based on the following criteria: (1) the company is, or is expected to become, one of the largest suppliers of energy, in terms of energy provided, to its country of origin; (2) the country of origin of the company is one of the Nordic countries; (3) the company has CSR and/or sustainability policies available online for public access; and (4) the company is a signatory of the United Nations Global Compact (UNGC). As additional criteria, the interview framework allowed cross-references as pointed out by the participants (i.e., the participants were asked to suggest potential participants that could be included in this research). This resulted in including five additional companies in the selection process.

Once the initial selection was completed, the potential participants were contacted via email, as well as through online contact forms on the company's websites, to ask for an interview with high-level CSR and/or sustainability managers. The initial selection of participants included twenty-five companies, from which eleven agreed to participate. The selected participants include companies from all Nordic countries and that operate most of the sources of energy available in the region (see Table 4). 
Table 4. Companies that participated in the study.

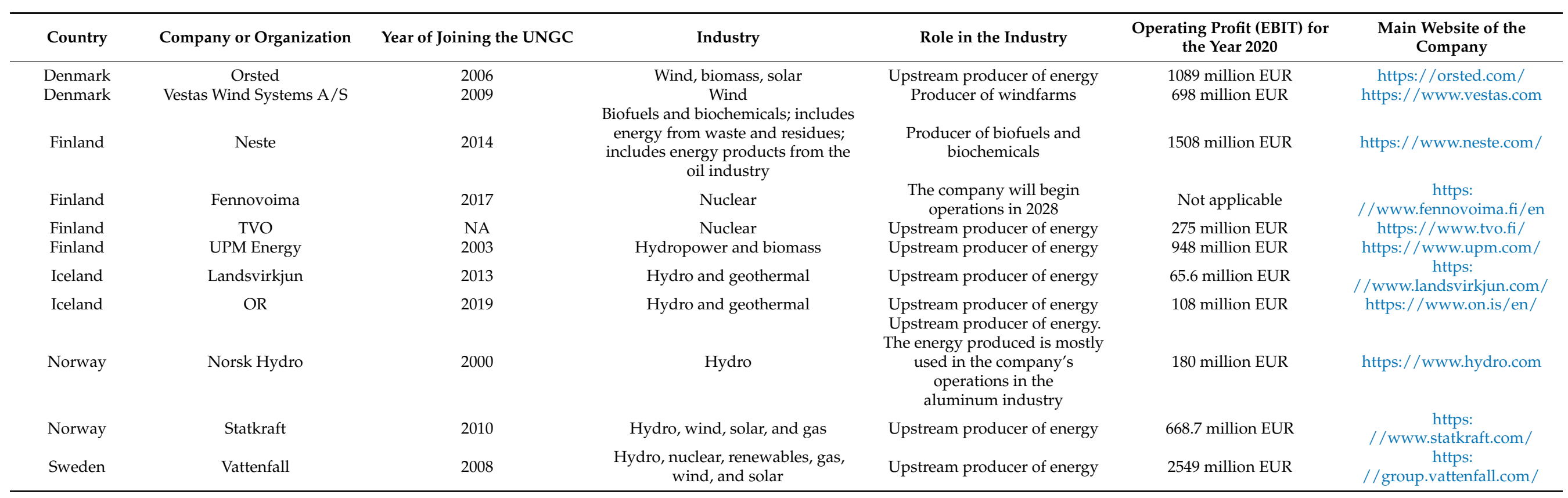

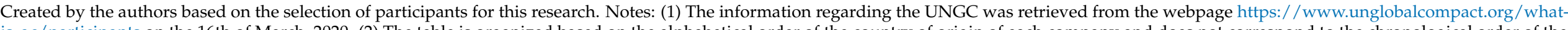

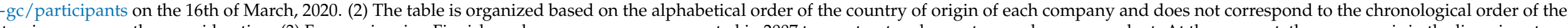

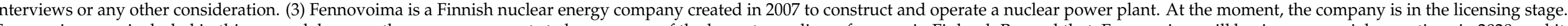

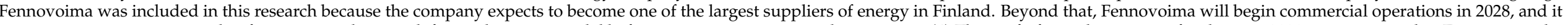

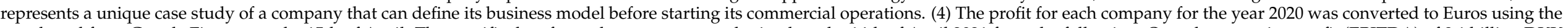

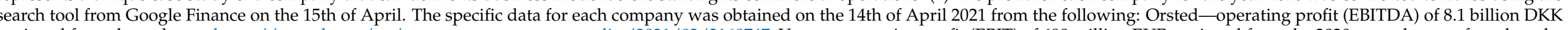

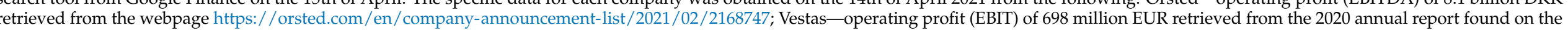

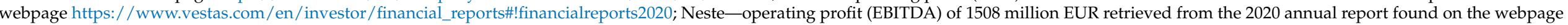

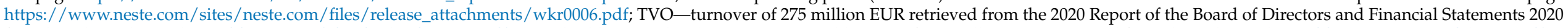

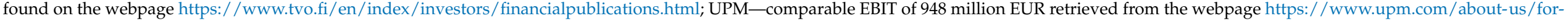

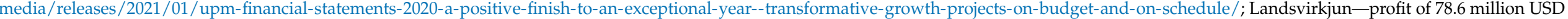

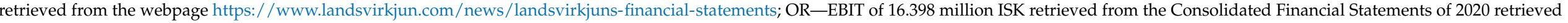

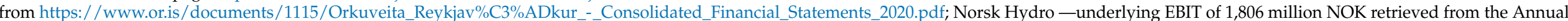

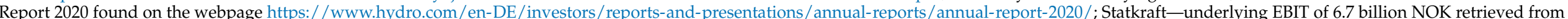

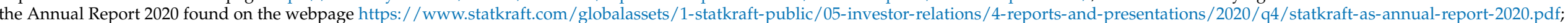
Vattenfall—underlying operating profit of 25,790 million SEK retrieved from the webpage https://group.vattenfall.com/press-and-media/pressreleases/2021/vattenfall--year-end-report-2020. 
Table 5 provides additional information about the selected companies by indicating their position in different rankings. The first two columns correspond to rankings that evaluate companies from any sector and industry from a CSR and sustainability perspective (CSRhub and Corporate Knights Top 100 Sustainable Companies), while the last two columns correspond to rankings that focus on the energy sector (Thomson Reuters Top 100 Energy Leaders and S\&P Global Platts 250 Energy Companies).

Table 5. Rankings of each company.

\begin{tabular}{|c|c|c|c|c|c|}
\hline \multirow{3}{*}{$\begin{array}{l}\text { Country of } \\
\text { Origin }\end{array}$} & \multirow{3}{*}{ Company } & \multicolumn{4}{|c|}{ Rankings } \\
\hline & & CSRhub & $\begin{array}{c}\text { Corporate } \\
\text { Knights Top } 100\end{array}$ & $\begin{array}{c}\text { Thomson Reuters } \\
\text { Top } 100 \\
\text { Energy Leaders }\end{array}$ & $\begin{array}{c}\text { S\&P Global Platts } \\
250 \text { Energy } \\
\text { Companies }\end{array}$ \\
\hline & & {$[\%]$} & [Ranking] & [Included] & [Ranking] \\
\hline Denmark & Orsted & $88 \%$ & 1 & Yes & 37 \\
\hline Denmark & Vestas & $95 \%$ & 37 & Yes & NI \\
\hline Finland & Neste Corporation & $92 \%$ & 3 & Yes & 84 \\
\hline Finland & UPM Energy & $97 \%$ & 24 & NI & NI \\
\hline Finland & Fennovoima & NI & NI & NI & NI \\
\hline Finland & TVO Finland & NI & NI & NI & NI \\
\hline Iceland & OR & NI & NI & NI & NI \\
\hline Iceland & Landsvirkjun & NI & NI & NI & NI \\
\hline Norway & Hydro & $94 \%$ & NI & NI & NI \\
\hline Norway & Statkraft & NI & NI & NI & NI \\
\hline Sweden & Vattenfall & $100 \%$ & NI & NI & NI \\
\hline
\end{tabular}

Created by the authors based on the selection criteria for this research. NI = not included; NA = not applicable. Notes: (1) The rankings from CSRHub were accessed online on 17 January 2020 from the webpage https:/ / www.csrhub.com. It is relevant to notice that CSRHub names several companies in a different way: Orsted as DONG; Vestas as Vestas Wind Systems; Neste as Neste Oil Oyj; UPM Energy as UPM-Kymmene Oyj; Hydro as Norsk Hydro. (2) The rankings from Thomson Reuters Global 100 Energy Leaders were found in the latest report available, which is for the year 2017. (3) The rankings from S\&P Global Platts Top 250 Energy Companies were found in the latest report, which is for the year 2019. (4) The rankings from Corporate Knights "Global 100 Most Sustainable Companies" were found in the report for the year 2020. It is relevant to notice that Corporate Knights names several companies in a different way: Neste as Neste Oyj and UPM as UPM-Kymmene Oyj. (5) The table follows the alphabetical order of the country of origin of each company and does not correspond to any other consideration. (6) While Fennovoima, TVO Finland, OR, and Landsvirkjun are not included in any of the rankings, they are of great relevance for this research. Fennovoima was included because the company is expected to become one of the largest suppliers of energy in Finland. Beyond that, Fennovoima will begin commercial operations in 2028, and it represents a unique case study of a company that can define its business model before starting its commercial operations. TVO Finland was included in this research because it is considered one of the most relevant energy companies in the country. OR and Landsvirkjun were included because they are the two largest energy companies in Iceland.

The selection of interviewees followed a purposive approach in which participants were identified specifically because of their experience in relation to the research at hand (see [88]). In this case, the interviewees were identified by each company given their role, position, and experience concerning CSR. In this process, Fennovoima asked to have two participants during one interview while Orsted granted two separate interviews. This led to having a total of twelve interviews with thirteen participants. Of the thirteen participants, eight were male and five female. Four participants asked to remain anonymous. All the interviewees are high-level managers with positions directly linked to the business development and CSR/sustainability of the company and have significant experience within the firm, which reinforces their relevance for this research. Furthermore, the role, experience, and position of the interviewees allows them to make deeper reflections about the individuals within the company, the organizational structure of the firm, and the institutional context where they operate.

\subsubsection{Interview Modality}

The location of the researchers, the characteristics of the study, and the preference of the participants to have a videoconference led to conducting nine interviews via videoconference and three face-to-face. 


\subsubsection{Conducting the Interviews}

The interviews were conducted between May and October 2019 as part of a broader research on Nordic energy companies. With the permission of the participants, all the interviews were recorded with the cellphone of the interviewer to be later transcribed. The language used during the interviews was English to keep a homogeneous interview framework. However, it is necessary to point out that English is not the mother tongue of any of the participants, including the researcher in charge of conducting the interviews.

\subsubsection{Transcription}

The audio recordings of the interviews were transcribed into a text file in Microsoft Word 2013 and were shared with those participants who asked to review them with the possibility of making changes to the text. The transcriptions were done by the interviewer, considering that it would allow a clearer understanding of the audio and the content of the interview.

\subsubsection{Extraction of Information and Data Analysis}

The extraction of information and the data analysis followed the research method proposed by Castleberry and Nolen [90] for conducting a thematic analysis and consisted of five steps: compiling, disassembling, reassembling, interpreting, and concluding. The compiling of data began by asking the participants if they would like to review the transcription of their interview with the possibility of making changes to the text. This systematic process is commonly used in qualitative research as a way of validating the trustworthiness of the interpretations made by the researcher (see [91]). After the participants agreed to the final version of the transcriptions, the next step consisted of transferring all the transcriptions to the software MAXQDA 2020. This allowed the researchers to easily see and organize the data within one unified software program. The disassembling consisted of a coding process to identify themes and concepts systematically. To do so, a coding frame and a coding manual were designed based on the method proposed by Schreier [92]. The design of the coding frame followed preconceived coding based on the categorization of the barriers to CSR found in the literature, which led to having a coding frame with seventeen preconceived codes. No additional codes were added during the extraction of information. The coding frame was defined to retrieve the relevant information from each interview, and allowed for its structuring and organization based on specific codes. Additionally, a coding manual was created to define specific considerations for the names for each code, their definitions, and the specific rules and considerations for the coding process. A pilot test was conducted on the longest and shortest interviews to test the consistency and validity of the coding frame and the coding rules. The reassembling was done through thematic matrices, which allowed the arrangement of the data based on preconceived codes as well as emerging concepts. This process consisted of continuous reviews to determine the relevance, consistency, and validity of the extracted data. The interpreting process, as explained by Castleberry and Nolen [90], was done while conducting the first three steps (compiling, disassembling, and reassembling). The interpreting process gave a higher priority to the relevance of each barrier to the participants and a lower priority to how often a theme/code was mentioned (based on [90]). However, the frequency in which a theme/code was mentioned helped validate its relevance to the participants and served as an initial way to test the consistency during the interpreting process. The concluding step was achieved after several iterations of the interpretation process, which allowed testing of the consistency of the conclusions. This iterative process is commonly used in qualitative research to confirm the reliability of the analysis and interpretation of data [91]. In this case, the iterations of the interpretation process allowed confirmation that different participants said similar things that complemented each other and that there was no indication of contradicting ideas. 


\section{Findings}

\subsection{Identification and Categorization of the Barriers}

This section focuses on the identification and categorization of the barriers through three levels of analysis: individual, organizational, and institutional.

\subsubsection{Barriers at an Individual Level}

This section considers the barriers at an individual level as those that are directly linked to the psychological, behavioral, or attention/focus aspects that affect individual decision-makers within the company. Based on the analysis of the interviews with highlevel managers, it was possible to identify seven barriers to CSR implementation at the individual level (see Table 6): company's negative contribution to society; decision-making based on egocentrism; lack of CSR fit, motivation, and commitment; lack of CSR knowledge and awareness; lack of CSR leadership; lack of organizational support; and negative attitude toward CSR.

Table 6. Barriers at the individual level of analysis.

\begin{tabular}{|c|c|c|c|}
\hline Barrier & Description & $\begin{array}{c}\text { Frequency } \\
\text { (\# Interviews) }\end{array}$ & Examples \\
\hline Lack of CSR leadership & $\begin{array}{l}\text { Individuals in the leadership and top } \\
\text { management do not support the CSR } \\
\text { agenda within the company. The } \\
\text { individual leaders do not drive } \\
\text { forward CSR within the company, } \\
\text { and as a result, it limits its effective } \\
\text { implementation. }\end{array}$ & 9 & $\begin{array}{l}\text {... our strategic shift is also very much } \\
\text { a decision that was based on our current } \\
\text { CEO and the one that we had before him } \\
\text {... we have been so much part of the } \\
\text { problem for so many years, so of course, it } \\
\text { makes a lot of sense for us to be that } \\
\text { change that the world needs to see } \\
\text { (interviewee \#5). }\end{array}$ \\
\hline $\begin{array}{l}\text { Lack of } \\
\text { organizational support }\end{array}$ & $\begin{array}{l}\text { Individual decision-makers perceive } \\
\text { a lack of organizational support. This } \\
\text { can result in lowering their focus and } \\
\text { motivation to drive forward the CSR } \\
\text { agenda of the company. }\end{array}$ & 8 & $\begin{array}{l}\text { An effective CSR agenda has to be built } \\
\text { from the bottom upwards together with } \\
\text { the personnel (interviewee \#3). }\end{array}$ \\
\hline $\begin{array}{l}\text { Negative attitude } \\
\text { toward CSR }\end{array}$ & $\begin{array}{l}\text { Individuals within the company can } \\
\text { have a negative attitude toward CSR. } \\
\text { This results in the failure to perceive } \\
\text { the benefits of CSR, which in turn } \\
\text { leads individual employees to not } \\
\text { fully support the company's CSR. }\end{array}$ & 8 & $\begin{array}{l}\text {... we found out that among our } \\
\text { employees, as well in other groups of } \\
\text { stakeholders, the word Corporate Social } \\
\text { Responsibility had this limitation of } \\
\text { capturing our work ... we found out } \\
\text { that, in the minds of the people, it was } \\
\text { something only focused on the social part } \\
\text { and not on the holistic approach that we } \\
\text { want to practice (interviewee \#12). }\end{array}$ \\
\hline $\begin{array}{l}\text { Lack of CSR } \\
\text { knowledge and } \\
\text { awareness }\end{array}$ & $\begin{array}{l}\text { Individuals within the company have } \\
\text { limited knowledge and } \\
\text { understanding of CSR. } \\
\text { Additionally, individual } \\
\text { decision-makers have limited } \\
\text { involvement in the company's CSR. } \\
\text { As a result, individuals frequently } \\
\text { find it difficult to learn more about } \\
\text { such activities and become involved } \\
\text { and committed to the } \\
\text { company's CSR. }\end{array}$ & 7 & $\begin{array}{l}\text { We really need competent and } \\
\text { knowledgeable staff members here, who } \\
\text { are well educated ... ... we are in a } \\
\text { really big competition within the different } \\
\text { companies to be able to recruit the needed } \\
\text { resources which we need. So, in the } \\
\text { future, that will be even more important } \\
\text { for us (interviewee \#9). }\end{array}$ \\
\hline
\end{tabular}


Table 6. Cont.

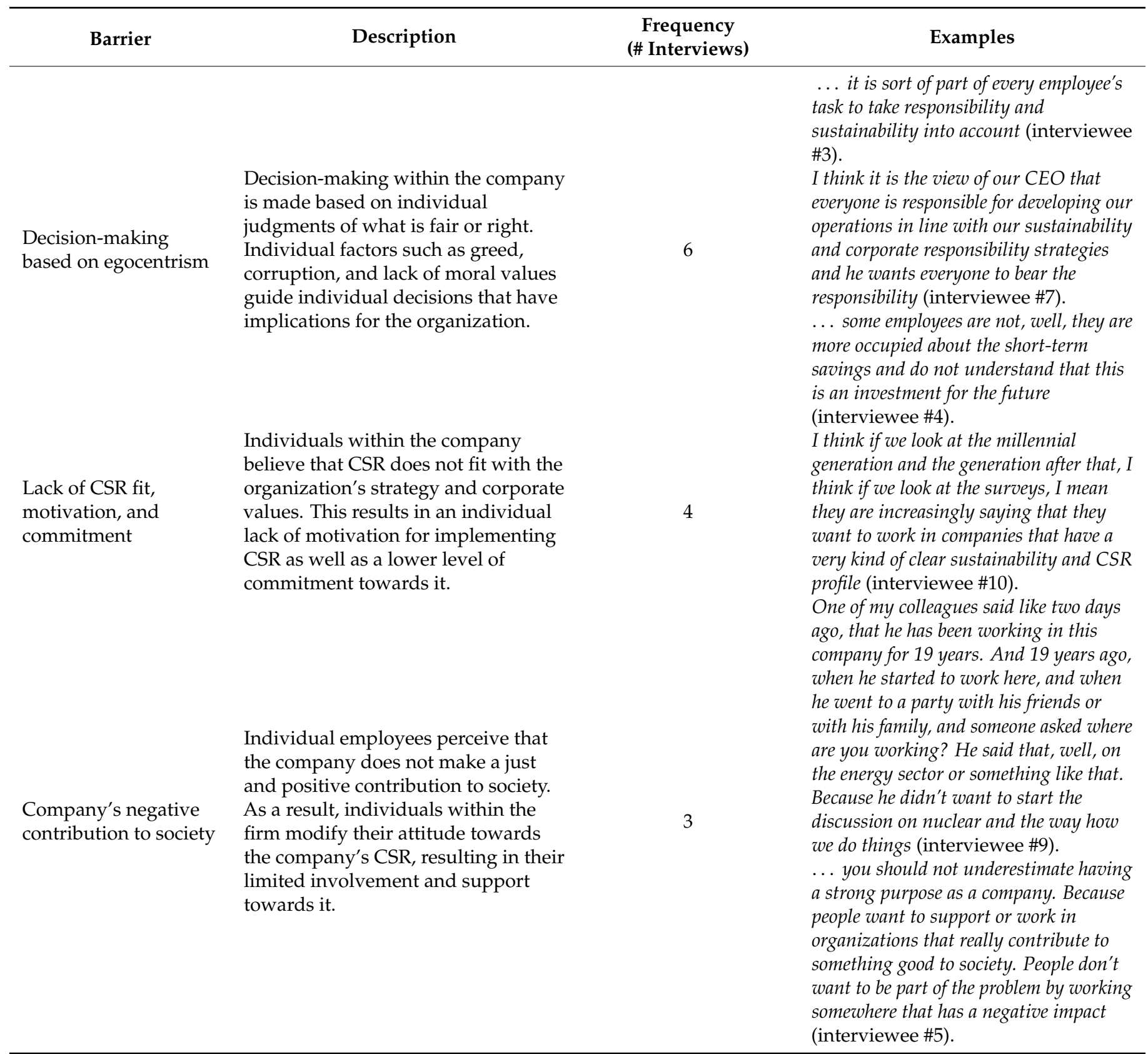

Created by the authors based on the analysis of the interviews and guided by the literature review conducted in Section 2. Notes: (1) The number assigned to each interviewee is only used to differentiate each participant. (2) The table is organized based on the frequency with which each barrier was mentioned and without any other consideration.

The analysis of the interviews suggests that the participants consider lack of CSR leadership as the main barrier. In this sense, the interviewees pointed out that leadership is a relevant element for giving the correct direction to the CSR and sustainability agenda of the company. Accordingly, the findings suggest that participants see a link between the company's lack of CSR leadership, the lack of organizational support, and the general negative attitude toward CSR within the company.

In a similar way, most of the participants explained that the effective implementation of CSR can be limited by the lack of CSR knowledge and awareness of the employees. This was particularly evident with participants from companies with operations in the nuclear industry, who explained that the effective implementation of CSR depends not only on the employee's CSR knowledge and awareness, but also on the belief that the company is making 
a positive contribution to society. In this sense, one participant mentioned that people don't want to be part of the problem by working somewhere that has a negative impact (interviewee \#5).

The findings suggest that decision-making based on egocentrism can hinder the effective implementation of CSR. The interviewees explained that the ability of employees to make decisions based on their conception of what is fair can become a limiting factor for the effective implementation of CSR. The participants indicated that relying on each employee to make the right choice is important for advancing the CSR and sustainability agenda of the company, and explained that a lack of CSR fit, motivation and commitment would limit their ability to do so.

Concerning the lack of CSR fit, motivation, and commitment, participants pointed out that companies depend on their employees' commitment and motivation to drive forward the CSR and sustainability agenda of the company. Notably, the findings suggest that there is a relation between the lack of CSR fit, motivation, and commitment and the lack of CSR knowledge and awareness within the company, which can reflect the relevance of training the staff on the topic. With regard to these aspects, two participants expressed the following:

"The company has to involve the personnel in the sort of idea sharing and planning and sharing the thoughts of what kind of new opportunities we would have with our agenda" (interviewee \# 3).

" ... our staff members have to be really competent and knowledgeable to be able to take care of the responsible aspects and sustainability aspects which we are responsible for" (interviewee \#9).

\subsubsection{Barriers at an Organizational Level}

This section considers the barriers at an organizational level as those that originate in organizational aspects linked to corporate culture, the organizational reward system and organizational inertia, and the interactions between the individuals within the firm. Based on the analysis of the interviews, it was possible to identify seven barriers at the organizational level (see Table 7): lack of flexibility and adaptability; lack of integration of CSR to the core business; lack of organizational trust; lack of understanding of the context; limited access to resources; misalignment of the corporate culture; and unfit organizational structure.

Table 7. Barriers at the organization level of analysis.

\begin{tabular}{|c|c|c|c|}
\hline Barrier & Description & $\begin{array}{c}\text { Frequency } \\
\text { (\# Interviews) }\end{array}$ & Examples \\
\hline $\begin{array}{l}\text { Lack of flexibility } \\
\text { and adaptability }\end{array}$ & $\begin{array}{l}\text { The company tends to resist change. } \\
\text { The organization is not flexible and able to } \\
\text { adapt to changing circumstances. } \\
\text { Flexibility and adaptability is usually } \\
\text { limited by routines, resource limitations, } \\
\text { and structural power struggles within the } \\
\text { company. }\end{array}$ & 9 & $\begin{array}{l}\text { We shifted our strategy a couple of years ago, } \\
\text { and coming from a very fossil-heavy asset } \\
\text { portfolio, realizing that, this is not the future } \\
\text { (interviewee \#1). } \\
\text {... we sold off our oil and gas business, which } \\
\text { basically meant that we would not invest in } \\
\text { fossil fuels anymore.... It was both a } \\
\text { business case decision, but it was very much } \\
\text { also a strategic decision that goes hand in hand } \\
\text { with responsibility (interviewee \#5). }\end{array}$ \\
\hline $\begin{array}{l}\text { Unfit } \\
\text { organizational structure }\end{array}$ & $\begin{array}{l}\text { The organization has certain roles and } \\
\text { responsibilities, as well as patterns of } \\
\text { interaction between individuals and } \\
\text { authority levels, that can limit the } \\
\text { company's capability to implement CSR. } \\
\text { This includes the limited capability of the } \\
\text { firm to establish internal structures to } \\
\text { ensure the compliance of CSR as the } \\
\text { company grows in size with new internal } \\
\text { departments and suppliers. }\end{array}$ & 9 & $\begin{array}{l}\text { We have not had a sustainability department } \\
\text { here in the company historically. So, all the } \\
\text { environmental issues have been with our } \\
\text { quality, safety and environment department, } \\
\text { and the social responsibility with the CSR } \\
\text { department. But now we are kind of creating } \\
\text { this umbrella function around this } \\
\text { (interviewee \#11). }\end{array}$ \\
\hline
\end{tabular}


Table 7. Cont.

\begin{tabular}{|c|c|c|c|}
\hline Barrier & Description & $\begin{array}{c}\text { Frequency } \\
\text { (\# Interviews) }\end{array}$ & Examples \\
\hline $\begin{array}{l}\text { Lack of understanding of } \\
\text { the context }\end{array}$ & $\begin{array}{l}\text { The organization lacks the knowledge or } \\
\text { capacity to implement CSR with a holistic } \\
\text { approach that goes beyond its areas of } \\
\text { operation and in accordance with the } \\
\text { context where it operates. } \\
\text { The company lacks the strategic capacity } \\
\text { to fully understand how to implement } \\
\text { CSR in a way that addresses aspects } \\
\text { related to its supply chain, regulations, } \\
\text { procedures, and standards, as well as in } \\
\text { relation to cultural and social aspects. }\end{array}$ & 8 & $\begin{array}{l}\text { We have been through a fairly challenging } \\
\text { situation during the last } 15 \text { months with the } \\
\text { embargo finally being lifted. That is an } \\
\text { example of how bad it can be when we are not, } \\
\text { when you don't have the right foresight... we } \\
\text { had seen the challenges we had there, but we } \\
\text { underestimated how severe they were. } \\
\text { (interviewee \#4 talking about an embargo } \\
\text { to one of their plants). }\end{array}$ \\
\hline $\begin{array}{l}\text { Limited access } \\
\text { to resources }\end{array}$ & $\begin{array}{l}\text { The company has limited access to } \\
\text { resources such as financial resources, } \\
\text { human capital, and access to market } \\
\text { opportunities. This limits its ability to } \\
\text { implement CSR. }\end{array}$ & 8 & $\begin{array}{l}\text { [In Rotterdam]... we have been able to recruit } \\
\text { the best talents, and this is not the case for } \\
\text { Finland, for instance. There is a limited } \\
\text { amount of competitors in this area, and } \\
\text { Finland, unfortunately, is not such an } \\
\text { attractive place for people from abroad to move } \\
\text { into. This is too far in the north (interviewee } \\
\# 2 \text { ). }\end{array}$ \\
\hline $\begin{array}{l}\text { Lack of } \\
\text { organizational trust }\end{array}$ & $\begin{array}{l}\text { The company lacks transparency and } \\
\text { accountability in relation to its } \\
\text { procurement process, as well as with } \\
\text { relations with internal and external } \\
\text { stakeholders. As a result, there is a lack of } \\
\text { trust in the company to deliver what they } \\
\text { promise in relation to CSR. }\end{array}$ & 7 & $\begin{array}{l}\text { Whenever other companies are not responsible, } \\
\text { or are not transparent, or are doing something } \\
\text { different from what they are saying, it's always } \\
\text { also a challenge for us. Because nuclear is kind } \\
\text { of sensitive business, ... and whenever there } \\
\text { happens something, even in another industry, } \\
\text { they might start thinking about that, well, they } \\
\text { are saying that they are doing things like that, } \\
\text { but how is it really in there? So, in the other } \\
\text { industries, they might be a challenge for us to } \\
\text { be responsible because then there might be } \\
\text { people who then wouldn't believe us even } \\
\text { though that we are doing things in a } \\
\text { responsible way. And it comes from the } \\
\text { sensitivity of the whole nuclear industry } \\
\text { (interviewee \#9). }\end{array}$ \\
\hline $\begin{array}{l}\text { Misalignment of the } \\
\text { corporate culture }\end{array}$ & $\begin{array}{l}\text { The corporate culture in the company is } \\
\text { not aligned with its CSR. This limits the } \\
\text { ability of CSR to guide the identity, } \\
\text { purpose, and direction of the company. }\end{array}$ & 6 & $\begin{array}{l}\text { There are some challenges with the company } \\
\text { culture when you are more than three } \\
\text { thousand people and you are present in sixteen } \\
\text { countries. As an international company, I do } \\
\text { not think we are very big, but we are very } \\
\text { diverse. There is heterogeneity among our staff } \\
\ldots \text {.. [and] it demands continuous training and } \\
\text { awareness internally in the company } \\
\text { (interviewee \#8). }\end{array}$ \\
\hline $\begin{array}{l}\text { Lack of integration of } \\
\text { CSR to the core business }\end{array}$ & $\begin{array}{l}\text { CSR is not fully integrated into the core } \\
\text { business of the organization. This limits } \\
\text { the effectiveness of CSR for the company. }\end{array}$ & 5 & $\begin{array}{l}\text { I think it is evident today, at least it is evident } \\
\text { to me, that unless you integrate sustainability } \\
\text { at the core of your business model you will not } \\
\text { be future-proofing your company, not setting } \\
\text { up for profitability in the long term, for } \\
\text { financial sustainability in the long term } \\
\text { (interviewee \#6). }\end{array}$ \\
\hline
\end{tabular}

Created by the authors based on the analysis of the interviews and guided by literature review conducted in Section 2. Notes: (1) The number assigned to each interviewee is only used to differentiate each participant. (2) The table is organized based on the frequency in which each barrier was mentioned and without any other consideration.

The majority of the participants pointed out the lack of flexibility and adaptability and organizational structure and size as the main aspects that can limit the effective implementation of CSR. Furthermore, most of the interviewees highlighted an interdependent relationship between the unfit organizational structure and the company's lack of flexibility and adaptability to changing market environments. This notion was particularly evident from two perspectives: (1) for companies with more than one hundred years of history; and (2) for companies that changed from a fossil-fuel-oriented portfolio to a diversified portfolio centered on renewable sources of energy. 
For participants from companies with a long history, the flexibility and adaptability of their companies have been a key element in their success and the implementation of their business strategies. In particular, interviewees expressed a clear belief that companies need to adapt to the evolution of energy markets, and to do so, they need to update and redesign their business models accordingly, otherwise they would fail in their responsibilities and would remain in an organizational inertia that would limit their capabilities and competitive edge. Perhaps the clearest example comes from one participant who mentioned that the company has been able to test its flexibility and adaptability several times through its history, and as a result, the company has expanded its market share and explored other products in a diversity of sectors and industries.

The participants from companies that changed their business portfolio from the oil and gas industries to focus on renewable sources of energy expressed that the flexibility and adaptability of their companies was a key element in adapting their strategies to better align with their CSR strategy. In this sense, the interviewees indicated that their business would have been limited if it did not have the flexibility and adaptability to change.

Similarly, the participants explained that the lack of understanding of the context represents a relevant challenge for organizations with operations in international markets where there are regulatory and cultural differences. For instance, one participant explained that the company faced a challenging situation with one of its international operations to the point that one of its plants underwent an embargo by the local government.

Participants also pointed out that big international companies face challenges related to their organizational structure and size, along with the context where they operate. The interviewees mentioned that having international operations translates into having a large number of employees with different cultural backgrounds. In the participants' view, having a large organizational structure and international presence represents relevant challenges concerning other aspects such as: having comprehensive management systems that can follow the practices and performance across the company's international operations; the need to follow different national legislations and regulations, as well as international laws; the relevance of understanding the geographical diversity of the company's portfolio; the large size of the company and the diversity of its employees demands constant training and awareness across the organization; and being faced with decision-making dilemmas when national or local legislation or regulation does not correspond to what the company considers fair or responsible behavior.

Another relevant aspect is that the findings suggest that a significant barrier comes from having limited access to resources. In this sense, the interviewees explained that nowadays investors and customers are looking for companies that are aware of their environmental and social impact and have a clear idea of how to mitigate their risks. The participants further explained that companies that are not aware of these aspects will not be able to have access to better offers from investors, such as borrowing capital at lower interest rates. Concerning access to human capital, the participants pointed out that there is a high competition for skilled employees, which represents a significant challenge for Nordic companies.

The lack of organizational trust was particularly highlighted by participants from companies with operations in the nuclear industry. The participants explained that the nuclear industry faces challenges concerning organizational trust that are specific to this industry, and explained them from two main perspectives: (1) having operations in the nuclear industry usually has political implications that depend on governmental support and social approval; and (2) nuclear companies are sensitive to the actions and responsible behavior of other nuclear firms around the world, which in turn might impact their social license to operate and their organizational trust. For instance, one interviewee mentioned the following:

"If we have an individual working on our site, for example in the control room, and he or she does something which is against our safety requirements, it's a hit against the whole industry. It's a hit against the whole company. It's actually a hit against the nuclear 
industry worldwide. So whatever happens, for example, in Japan or the Czech Republic, or any other country using nuclear power plants, has an influence on us" (interviewee \#9).

\subsubsection{Barriers at an Institutional Level}

This section considers the barriers at an institutional level as those that go beyond individual organizations and are linked to aspects at a macro level, such as standards and regulations and mimetic organizational tendencies, as well as the belief and value systems that prevail in the institutional context. Based on the analysis of the interviews, it was possible to identify three barriers at the institutional level (see Table 8): cognitive; normative, and regulatory.

Table 8. Barriers at the institutional level of analysis.

\begin{tabular}{|c|c|c|c|}
\hline Barrier & Description & $\begin{array}{c}\text { Frequency } \\
\text { (\# Interviews) }\end{array}$ & Examples \\
\hline Normative barriers & $\begin{array}{l}\text { The institutional context is greatly } \\
\text { influenced by the belief system and } \\
\text { accepted set of norms that prevails. } \\
\text { This can influence individual } \\
\text { decision-makers within the } \\
\text { organization, as they are exposed to } \\
\text { certain education and training } \\
\text { activities, as well as to local and } \\
\text { global standards based on their } \\
\text { networks, educational background, } \\
\text { and demography. } \\
\text { They are also influenced by operating } \\
\text { in a specific industry that follows } \\
\text { certain standards, operating } \\
\text { procedures, and criteria. As a result, } \\
\text { the normative context can negatively } \\
\text { influence the adoption and } \\
\text { implementation of CSR. }\end{array}$ & 7 & $\begin{array}{l}\text {... the whole climate debate has been } \\
\text { very much a factor in all this too. I think } \\
\text { it has become more and more clear that } \\
\text { the world is not, and has not been on a } \\
\text { sustainable path by any means, and as a } \\
\text { company, you have a responsibility to } \\
\text { address that. Especially the kind of } \\
\text { company that we are, we have been so } \\
\text { much part of the problem for so many } \\
\text { years, so of course, it makes a lot of sense } \\
\text { for us to be that change that the world } \\
\text { needs to see (interviewee \#5). } \\
\text {.. we are often invited to all kinds of } \\
\text { events and forums for energy } \\
\text { sustainability and so on, and I think we } \\
\text { also started to realize that compared to } \\
\text { other companies, that we are not so } \\
\text { advanced when it comes to the internal } \\
\text { part of sustainability, such as our carbon } \\
\text { footprint and so on (interviewee \#10). } \\
\text { When being in an area where the } \\
\text { insufficient social structure, with low } \\
\text { levels of education, with lack of proper } \\
\text { infrastructure like clean water, sewages, } \\
\text { et cetera, we are certainly at risk of being } \\
\text { expected to pay for investments that } \\
\text { should certainly be the authority's } \\
\text { responsibility (interviewee \#4). } \\
\text { The public atmosphere or the climate } \\
\text { regarding the different energy sources } \\
\text { hasn't been as open as it is currently. } \\
\text { And I think that kind of the } \\
\text { understanding of climate change and the } \\
\text { understanding of all of these issues is } \\
\text { now higher than it used to be earlier. So } \\
\text { now it's also easier for us to re-frame } \\
\text { these things like we have now done } \\
\text { (interviewee \#9 referring to their } \\
\text { operations in the nuclear industry). }\end{array}$ \\
\hline
\end{tabular}


Table 8. Cont.

\begin{tabular}{|c|c|c|c|}
\hline Barrier & Description & $\begin{array}{c}\text { Frequency } \\
\text { (\# Interviews) }\end{array}$ & Examples \\
\hline Regulatory barriers & $\begin{array}{l}\text { Corporate behavior is greatly } \\
\text { influenced by the political context, } \\
\text { along with legislations and } \\
\text { regulations, as well as compliance } \\
\text { and enforcement aspects. This } \\
\text { influence can limit the company's } \\
\text { capacity to operate in congruence } \\
\text { with what it considers to be } \\
\text { responsible, and can limit the } \\
\text { effective implementation of its CSR. }\end{array}$ & 5 & $\begin{array}{l}\text { We like stability, and I mean, we don't } \\
\text { work in unstable countries. I mean you } \\
\text { couldn't (interviewee \#1). } \\
\text {.. . we can't build new water reservoirs. } \\
\text { That depends on several things. One } \\
\text { thing is that it is, on a general basis, very } \\
\text { difficult to get the licenses for doing it, } \\
\text { but the most important for us today is } \\
\text { that as a private company we cannot get } \\
\text { that license ... But there have been } \\
\text { changes in the legislation so that if we } \\
\text { merge our reservoirs that are subject to } \\
\text { reversion with a public company, a } \\
\text { company owned by the authorities, we } \\
\text { can still keep our electricity } \\
\text { (interviewee \#4). } \\
\text { In Finland, nuclear is completely } \\
\text { privately owned. So we don't have any } \\
\text { subsidies from the state or we don't a } \\
\text { have governmental-issued part of the } \\
\text { owner. And that is something which is } \\
\text { completely different in Finland compared } \\
\text { to other countries ... . either the } \\
\text { government is the main owner of the } \\
\text { nuclear facilities or they are providing } \\
\text { quite a lot of subsidies on taxes or } \\
\text { something like that (interviewee \#9). }\end{array}$ \\
\hline
\end{tabular}

Created by the authors based on the analysis of the interviews and guided by the literature review conducted in Section 2 . Notes: (1) The number assigned to each interviewee is only used to differentiate each participant. (2) The table is organized based on the frequency in which each barrier was mentioned and without any other consideration.

Most participants emphasized that the European context plays a significant role in driving the responsible behavior of energy companies operating within Europe and explained that it represents an influence of normative and regulatory character that is the result of stringent regulatory frameworks, increased consumer awareness, and environmental and social requirements to and from suppliers and investors. However, the participants explained that the normative and cognitive influence found in the European context is not common in other geographical areas, and pointed out that companies that operate in unstable markets and unstable political situations face normative and cognitive barriers that hinder their capacity to implement CSR. Moreover, for the participants, these uncertainties limit the company's ability to implement CSR and reduce their interest in operating in certain countries, and as a result, "you avoid those countries" (interviewee \#1).

In a similar way, the majority of the participants mentioned that the institutional context where a company operates has a direct and indirect influence on its corporate behavior. The interviewees explained this notion by pointing out that operating outside of the Nordic and European context represents a diversity of challenges for acting in congruence with what they understand as CSR. To exemplify this, the interviewees explained that the challenges begin with aspects of cognitive nature, such as different expectations from stakeholders and society, and are complemented with aspects of a normative character, such as having international staff that have a diverse cultural and educational background and that follow a diversity of religions.

Another relevant aspect brought up by the interviewees is that having a large and international supply chain represents normative and cognitive barriers that influence the implementation of CSR. In this sense, the participants explained that there are challenges related to procurement aspects when the company has large supply chains that operate in 
different regulatory and cultural environments. For instance, one participant mentioned the following:

"One very important topic in the responsible business practices is that all the companies in the supply chain need to follow our code of conduct, they need to follow our requirements for their operations" (interviewee \#7).

Furthermore, the participants explained that the cognitive and normative aspects of operating in the Nordic countries are different from other parts of the world, and pointed out that a relevant challenge for their international operations comes from the ability to ensure the protection of human rights and the use of sustainable processes across their supply chain. Several participants stressed that sometimes only a limited number of suppliers can provide products and/or services that follow the standards set by the company. The interviewees explained that this limitation represents two barriers for ensuring an effective implementation of CSR that includes their supply chain:

(a) Sometimes the company has to pay a higher price or a premium to ensure that its supplies come from organizations that follow the highest environmental and social standards. As a result, paying a higher price for supplies can result in higher operational costs for the firm.

(b) The company needs to conduct regular audits in its supply chain to ensure the protection of human rights and the following of the highest environmental and social standards. This represents a relevant challenge for companies that do not have enough resources to conduct audits or do not have the organizational structure and procedures to implement routines and controls for monitoring these aspects internally and across the supply chain.

While the participants talked about the European and Nordic context as a whole, they also explained that the regulatory frameworks and the political decisions in the Nordic countries reflect specific cognitive and normative aspects that prevail in each Nordic society. This suggests that the interviewees consider the Nordic energy sector as a specific institutional context. In this sense, one participant pointed out that recent political agreements have resulted in the lifting of taxes on nuclear and hydropower energy in Sweden. Another participant explained that the Norwegian government now considers water reservoirs as a national good, and as a result, private energy companies are not able to get the licenses for additional water reservoirs needed for new hydropower projects. In this sense, one interviewee stressed the following:

"If you look at where we are investing in renewables ... you will find the effects of permits, procedures, and subsidies. We will of course invest where is cheapest, easiest, smoothest, and most efficient" (interviewee \#1).

In a similar manner, participants from companies in the nuclear industry explained that the specific cognitive and normative barriers that prevail in the countries where they operate play a significant role in the way they approach and implement CSR. In particular, the interviewees explained that the nuclear industry faces cognitive barriers that can translate into political and regulatory limitations for their operations, which suggests that the nuclear industry faces industry-specific barriers. This was explained by the interviewees in the following way:

"The support of nuclear energy is growing ... but there are then people who are afraid of nuclear just because of the accidents that have taken place and the final disposal of the fuel. So, there are some things that are important for people even though it is $\mathrm{CO}_{2}$-free" (interviewee \#7).

"The atmosphere in the country regarding the different electricity production is completely different, for example, in Germany, and Scandinavia. In Finland, $49 \%$ of our population is pro-nuclear and less than $20 \%$ are against nuclear, and these are the highest rates that we have ever had" (interviewee \#9). 


\section{Discussion}

The aim of this research was to answer two questions: (1) Which barriers do Nordic energy companies face in the implementation of Corporate Social Responsibility? (2) How do the barriers faced by Nordic energy companies influence the implementation of "implicit" and "explicit" Corporate Social Responsibility?

Concerning the first question, the analysis of the findings indicates that high-level CSR and sustainability managers from Nordic energy companies recognize a diversity of barriers in the implementation of CSR. This is consistent with the literature on the barriers to CSR implementation (see $[8,11]$ ) that follows the notion of institutional theory, which explains that organizational behavior cannot be understood without considering its societal context $[79,83]$.

The findings are consistent with the barriers to CSR implementation identified by the literature in three ways. First, the analysis indicates that interviewees identify barriers at the three levels of analysis but perceive that the most significant barriers are industry-specific, which coincides with the literature that points out industry-specific barriers (see $[10,55,75])$. This was evident in the interviews with participants from companies with operations in the nuclear industry, where industry-specific barriers were pointed out at the individual (lack of CSR knowledge and awareness, decision-making based on egocentrism, and company's negative contribution to society), organizational (lack of organizational trust), and institutional level of analysis (cognitive, normative, and regulatory barriers). Second, the findings suggest that some barriers can be associated with the size of the company, which aligns with the literature (see $[5,6,15])$. The interviewees pointed out that large and international energy companies face barriers at the organizational (misalignment of the corporate culture and unfit organizational structure) and institutional level (cognitive, normative, and regulatory barriers) in a similar way as pointed out by the literature (see $[5,16,82])$. Third, the analysis suggests that the company's negative contribution to society is a relevant barrier at the individual level for Nordic energy companies. In specific, the interviewees emphasized that the negative perception of the company's contribution to society can limit employee motivation and commitment, which coincides with previous studies on the topic (see $[25,59,66])$ and with the notions of the micro-foundations of CSR (see [60-62,64]). This suggests that the micro-foundations of CSR are of relevance for preventing or limiting the barriers at the individual level of analysis.

However, the findings differ from the literature on the barriers to CSR implementation in two key aspects. First, the overall analysis suggests that institutional barriers play a bigger role in the implementation of CSR by Nordic energy companies than expected based on the literature (see $[14,24])$. In particular, the interviewees highlighted that Nordic energy companies avoid having operations in energy markets that do not have stable economies or developed regulatory frameworks because such a context can translate into relevant barriers to their CSR implementation. This suggests that Nordic energy companies prefer to operate within their institutional context, and avoid facing additional institutional barriers by operating outside the Nordic context. This is consistent with the notions of institutional theory, which indicates that organizational behavior can only be understood taking into consideration its societal context, and that organizational behavior is constrained by its institutional context (see [79]). However, the answers from the interviewees from companies with operations in the nuclear industry suggest that they face institutional barriers that are industry-specific. The findings also suggest that the involvement of the state in the energy sector does not have any relation with the barriers to CSR, even though it can have a direct and indirect influence on the institutional context where the companies operate.

Second, while the literature points out barriers directly linked to the context where a company operates, it mainly focuses on aspects that differ from the Nordic energy sector. For instance, the literature indicates institutional barriers such as lack of governmental support and legal infrastructure, unclear project requirements, and lack of law enforcement and societal awareness (see $[7,14,55,78])$, none of which were mentioned by the participants, 
and none of which are considered common in the Nordic countries. This suggests that Nordic energy companies face different institutional barriers than those identified in the literature.

It is relevant to highlight that even when the specific literature on the barriers to CSR points out that limited access to resources can be a barrier at the organizational level (see $[9,15,55])$, publications grounded on environmental collaboration and social impact suggest that it can lead to significant collaboration (see $[93,94])$. This is of relevance considering that the companies included in this study are some of the largest Nordic energy companies, and as such, they can be expected to play a significant role in terms of crosssector collaboration.

Based on the findings, this research identified and categorized seven barriers at the individual level of analysis, seven at the organizational level, and three at the institutional level. This categorization provides empirical evidence of barriers that have already been identified by the literature.

The barriers to CSR implementation have already been analyzed from different perspectives based on the size (e.g., [5,6]), national or regional context (e.g., [7-9]), and the industry where the company operates (e.g., $[10,11])$, but it seems that only Garavan, Heraty, Rock, and Dalton [16] have provided a holistic overview of the barriers that considers the interrelation and interaction between them, considering three levels of analysis (individual, organizational, and institutional).

While Garavan, Heraty, Rock, and Dalton [16] identified and categorized the barriers at the individual, organizational, and institutional level of analysis, their research was theoretical and focused on human resource development for conceptualizing the behavioral barriers to CSR. This research differs from the work of Garavan, Heraty, Rock, and Dalton [16] in the sense that it is based on empirical evidence to provide a closer look at the barriers that Nordic energy companies face in the implementation of CSR to provide a deeper understanding of the barriers and the interaction between them at an individual, organizational, and institutional level. Beyond that, this research complements the existing literature by identifying and categorizing the barriers based on empirical evidence, which allowed the proposal of a model (see Figure 2) to provide a broader perspective of the barriers to CSR in the Nordic energy sector.

The overall analysis suggests that Nordic energy companies face direct and indirect barriers across the three levels of analysis. This is consistent, to a certain extent, with the influence of the micro and macro-environment on CSR implementation suggested by Yuen and Lim [10], and the CSR cultures within an organization as suggested by Duarte [78]. However, this research differs from the literature by focusing specifically on the Nordic energy sector through an institutional approach that places corporate behavior at the center of analysis.

This research proposes a model (see Figure 3) that depicts the direct and indirect barriers to CSR based on empirical data from the energy sector. The model was designed based on the following considerations:

Direct barriers are those where the company can take preventive and proactive actions to limit its influence over the organization. This means that the company has a direct interaction with the barriers. For example, the lack of CSR leadership can be a barrier to the effective implementation of CSR. However, this barrier depends only on the company's actions.

Indirect barriers are those that prevail regardless of any actions taken by the company. This implies that the company does not have direct interaction with these barriers. For example, legislative and regulatory frameworks where a company operates can be barriers to the implementation of CSR. This means that these frameworks do not depend directly on the company, even when they influence it. 


\section{INDIVIDUAL}

\section{- Company's negative contribution to society}

- Decision-making based on egocentrism

- Lack of CSR fit, motivation \& commitment

- Lack of CSR knowledge \& awareness

- Lack of CSR leadership

- Lack of organizational support

- Negative attitude toward CSR
OR GANIZATIONAL

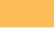

- Lack of flexibility \& adaptability

- Lack of integration of CSR to the core

business

- Lack of organizational trust

- Lack of understanding of the context

- Limited access to resources

- Misalignment of the corporate culture

- Unfit organizational

structure

\section{INSTITUTIONAL}

- Cognitive

- Normative

- Regulatory

Figure 2. Barriers to CSR. Created by the authors based on the analysis of the interviews and guided by the literature on the barriers to CSR.

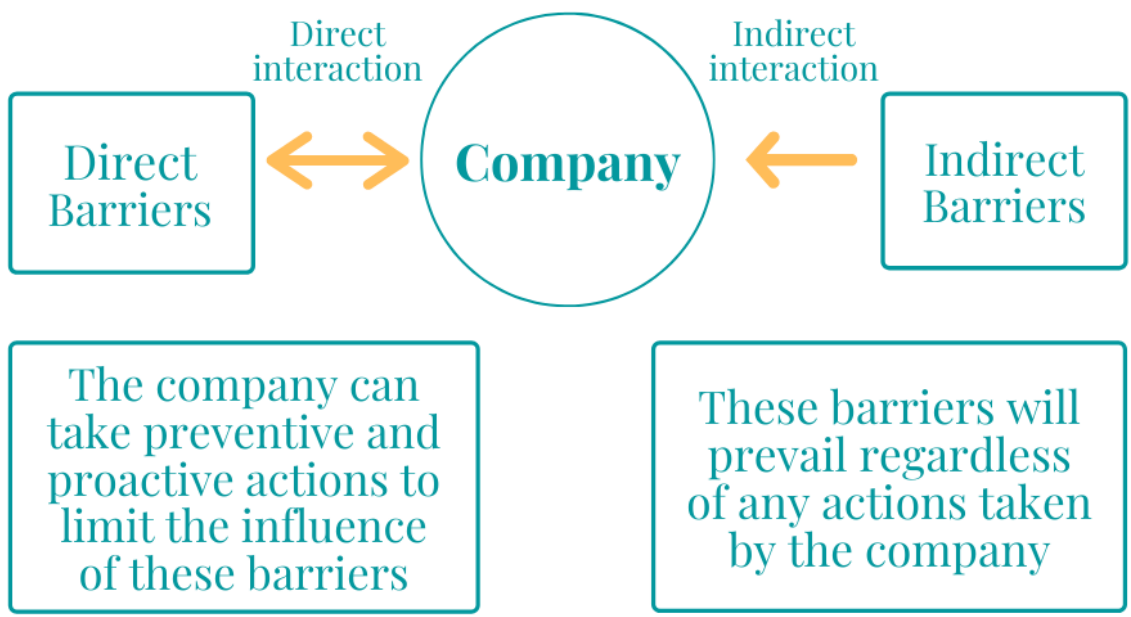

Figure 3. Direct and indirect barriers to CSR. Created by the authors based on the analysis of the interviews. Note: The arrows reflect the interaction of the barriers with the company. As can be observed, the direct barriers have a two-way interaction with the company, while the indirect barriers only have a one-way interaction with the organization.

Based on these considerations, it is possible to categorize the barriers found in this research as direct and indirect within the three levels of analysis. The analysis suggests that there are direct barriers at the three levels of analysis, while there are indirect barriers only 
at the organizational and institutional levels (see Table 9). The analysis suggests that direct barriers have a two-way interaction with the company, while indirect barriers only have a one-way interaction with the organization. The categorization proposed in Table 9 indicates that most of the barriers have direct interaction with the company, which suggests that the majority of barriers depend on the company's actions towards them. This means that organizations have the potential to take preventive and proactive actions to limit the direct barriers they face. The overall analysis suggests that the direct barriers at the individual level of analysis, in particular those that are linked to employee's attitude toward CSR, could be prevented or limited with low-cost solutions involving training and education of the staff. For instance, by improving the CSR knowledge and awareness of the employees, the company could reduce the negative attitude toward CSR, while at the same time increasing the motivation and commitment towards the firm's CSR.

Table 9. Direct and indirect barriers.

\begin{tabular}{|c|c|c|}
\hline Levels of Analysis & Direct Barriers & Indirect Barriers \\
\hline Individual & 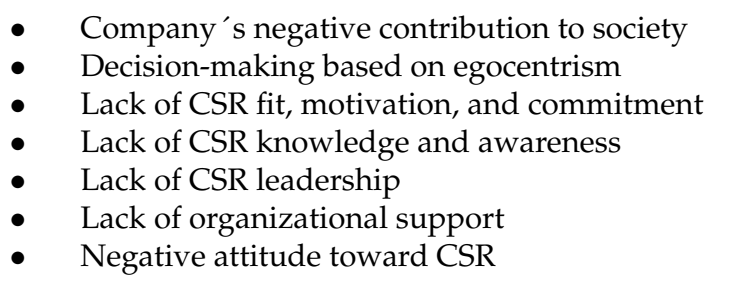 & \\
\hline Organizational & 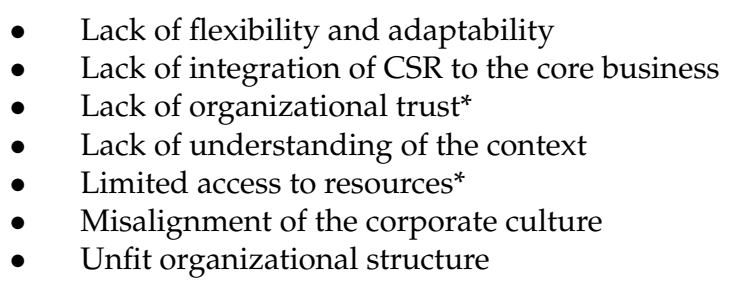 & $\begin{array}{l}\text { - Limited access to resources * } \\
\text { - Lack of organizational trust * }\end{array}$ \\
\hline Institutional & - $\quad$ Cognitive * & $\begin{array}{ll}- & \text { Cognitive * } \\
\text { - } & \text { Normative } \\
\text { - } & \text { Regulatory }\end{array}$ \\
\hline
\end{tabular}

Created by the authors based on the analysis of the interviews. Note: the barriers with an * can be either of a direct or indirect character, and are specific to each company.

Concerning the second question, the overall analysis of the findings suggests that Nordic energy companies implement CSR through an implicit or an explicit approach, which coincides with the theoretical framework proposed by Matten and Moon [85]. The implicit implementation of CSR was evident at the individual and organizational level of analysis when participants pointed out that decision-makers within energy companies, as well as people looking for jobs in the Nordic energy sector, want their organizations to contribute positively to society and align with their values. This is consistent with the relatively recent trend in which talented employees prefer to develop their career paths in companies with solid CSR commitments (see $[12,25,95]$ ). As a result, it possible that this trend can have an influence on the implicit or explicit implementation of CSR in the future. Furthermore, the analysis of the findings suggests that the motivations for implicit CSR can be influenced by barriers at the individual level such as decision-making based on egocentrism, lack of CSR knowledge and awareness, and lack of CSR leadership. The explicit implementation of CSR was mainly observed at the institutional level of analysis in companies operating in the nuclear industry. This was evident when participants talked about the perception of the nuclear industry and how some companies re-framed their activities based on the public debate around nuclear energy, which raises questions regarding their environmental 
and social claims. The analysis indicates that the motivations for explicit CSR are more evident for companies operating in the nuclear industry. This suggests that the motivations for explicit CSR can be influenced by barriers at the institutional level of analysis, and in particular, by cognitive barriers. While the findings suggest that the implicit implementation of CSR is present in the majority of the Nordic energy companies analyzed, they also indicate that some energy companies are implementing CSR in an explicit manner as a way of improving their social license to operate. Even when Matten and Moon [85] pointed to an increasing tendency towards the explicit implementation of CSR in Europe, the findings suggest that the expansion of explicit CSR in the Nordic energy sector has not been as rapid as they proposed. This could be an indication that the implementation of implicit and explicit CSR is not only influenced by factors at the institutional level, but also by factors at the individual and organizational level, as well as by industry-specific aspects.

\section{Conclusions}

Energy companies face a diversity of barriers in the implementation of CSR. These barriers can be at the individual, organizational, or institutional level, and can be of a direct or indirect nature in their interaction with the company. While the body of literature on CSR is vast and keeps growing, the attention on the barriers to CSR has been limited, and the barriers for Nordic energy companies have been missing from scholarly research. The objective of this research was fulfilled by identifying and categorizing the barriers that Nordic energy companies face in the implementation of CSR. This research provides an in-depth analysis of empirical data that contributes to the literature and can help complement existing publications on the topic. Accordingly, this research can serve as a starting reference for future studies that focus on the barriers to CSR in the energy sector. This research is grounded on institutional theory with a focus on Nordic energy companies to provide empirical evidence of how organizational behavior influences and is influenced based on the societal context of its operations.

\subsection{Main Contributions}

The main contributions of this article are: (1) it identifies and categorizes the different barriers that Nordic energy companies face in the implementation of CSR; (2) it defines the barriers to CSR as direct and indirect based on their interaction with the company; (3) it presents two models to give a broader perspective of the barriers to CSR and provides empirical evidence that helps complement the existing literature on the topic; and (4) it contributes to the literature on CSR by focusing on the Nordic countries, a region that has received a low level of attention by scholarly research on CSR, even though Nordic companies are ranked at the top of business rankings and are considered leaders in sustainability.

\subsection{Implications for Theory}

The theoretical contributions of empirical research come from theory testing and refinement [96] and from providing new insights and conceptualizations to existing theories $[97,98]$. This research contributes to two branches of CSR theory: the theoretical framework of implicit and explicit CSR and the theoretical approach to the barriers to CSR. By providing new insights and conceptualizations, this research helps improve the explanatory power of both theoretical branches. The main theoretical contributions are: (1) This article provides new insights into the framework of "implicit" and "explicit" CSR proposed by Matten and Moon [85]. Based on institutional theory [84,99,100], Matten and Moon [85] suggest an increasing tendency towards the "explicit" implementation of CSR in Europe, which can be explained by the homogenization of the institutional environment through the standardization of practices across industries and national boundaries. While the findings indicate that the "explicit" approach to CSR is present in Nordic energy companies, they suggest that the "implicit" approach remains relevant, in particular at the individual and organizational level of analysis. Furthermore, the findings suggest that the "explicit" 
implementation of CSR in the Nordic energy sector is evident in companies operating in the nuclear industry with the aim of improving their social license to operate. These aspects suggest that the "implicit" and "explicit" implementation of CSR is not only influenced by the institutional context, but also by factors at the individual and organizational level, as well as by industry-specific aspects. (2) This article provides new insights into the theory on the barriers to CSR, which can help improve the understanding and better explain the barriers as a relevant and current phenomenon. First, the identification of barriers at the three levels of analysis (individual, organizational, and institutional) serves as a theorytesting mechanism for previous studies (e.g., $[15,55,56])$. Second, this article contributes to CSR theory by proposing a new conceptualization of the barriers by defining them as direct and indirect based on their interaction with the company. This conceptualization can help improve the understanding of the barriers as a relevant cross-sector phenomenon and can serve as a starting reference for future theoretical studies on the interaction of the barriers with the company.

\subsection{Implications for Cleaner Production and Policymakers}

The findings have implications for cleaner production as well as for policymakers, governmental institutions, energy companies, and other practitioners in the energy sector in two ways: (1) This article provides a starting reference for the identification of barriers at the individual, organizational, and institutional level for the energy sector. This can help practitioners identify and minimize the influence of barriers to the implementation of CSR. Minimizing the barriers to CSR is particularly relevant considering that the energy sector is crucial for achieving most of the SDGs. (2) This article provides a new conceptualization of the barriers as direct and indirect based on their interaction with the company. Understanding the nature of the barriers as direct and indirect can help practitioners prioritize their efforts in dealing with such barriers. For example, the prioritization can be from a human resource management perspective within the company, to minimize the barriers at the individual level; from a strategic management perspective, to minimize the barriers at the organizational level; and from a governmental and stakeholder perspective, to minimize the barriers at the institutional level.

\subsection{Limitations of the Research}

The main limitations of this research come from having specific selection criteria that centered on the largest suppliers of energy in the Nordic region, which in turn excluded smaller firms. The study was also limited to companies with operations in the Nordic countries with CSR and/or sustainability policies available online for public access. Conducting the research and interviews in English could also be considered a limitation if some of the potential interviewees do not have a good command of the language. Nevertheless, the findings represent opportunities for future research that takes a closer look at the barriers to CSR implementation in other sectors, industries, and regions.

\subsection{Future Studies}

The pressing challenges to address and achieve the SDGs and complete the energy transition towards renewable sources of energy represent opportunities for conducting high-impact research that can advance the knowledge of the topic, and at the same time, help managers in their decision-making processes. It is relevant to consider that the literature focused on the barriers to CSR is limited, and the topic has not been covered with regards to the energy sector. Beyond that, empirical research is usually limited to specific selection criteria and needs to be updated periodically, which means that further research focused on the Nordic energy sector as well as on other energy markets should be conducted. With this in mind, it is possible to indicate opportunities for future research on the topic.

To begin with, it would be of academic and managerial interest to expand the theoretical and empirical research to other geographical areas that are not as regulated or as 
evolved as the Nordic and European energy sectors. This would allow the uncovering of additional barriers that energy companies face in different energy markets and different contexts. For example, significant research opportunities could arise from focusing on geographical areas with large populations that are expected to have a significant increase in their energy demand per capita (e.g., some of the Asian, African, and Latin American energy markets). It would also be of academic interest to further explore how energy companies can reduce the influence of direct barriers that affect their implementation of CSR. Finally, additional research is needed to understand if the indirect barriers to CSR are a limiting factor in the transition towards renewable sources of energy, and how their influence can be reduced.

Author Contributions: This paper is derived from M.L.'s work towards a Ph.D. in Environment and Natural Resources at the University of Iceland. As such, M.L. conducted the literature review, the research, and drafting for this article. L.J., being the main advisor for M.L.'s Ph.D. and B.D. and M.M., being members of the Ph.D. committee, contributed by guiding the direction and formulation of the article through comments, suggestions, information, and literature, and by contributing to the drafting and revising of the work to achieve the academic quality required for a Ph.D. at the University of Iceland. L.J. has provided the overall review. Conceptualization, M.L., L.J., B.D. and M.M.; data curation, M.L.; formal analysis, M.L.; funding acquisition, M.L.; investigation, M.L.; methodology, M.L.; project administration, M.L.; resources, L.J., B.D. and M.M.; software, M.L.; supervision, L.J., B.D. and M.M.; validation, L.J., B.D. and M.M.; visualization, M.L.; writing一original draft, M.L.; writing-review \& editing, L.J., B.D. and M.M. All authors have read and agreed to the published version of the manuscript.

Funding: We are grateful and acknowledge that this research was made possible by the support of the Mexican National Council for Science and Technology (CONACyT, for its abbreviation in Spanish) which granted a 36-month scholarship to M.L. to conduct his Ph.D. at the University of Iceland. We also want to thank the institutions that provided support and/or funds towards this research, which include the Landsvirkjun Energy Research Fund, the Erasmus+ Programme of Higher Education studies and traineeships, and the University of Iceland.

Institutional Review Board Statement: Not applicable.

Informed Consent Statement: Informed consent was obtained from all subjects involved in the study.

Data Availability Statement: Not applicable.

Acknowledgments: We want to thank all the experts from the Nordic energy companies who agreed to be interviewed. We also want to thank the Mistra Center for Sustainable Markets at the Stockholm School of Economics, in particular to Mette Morsing, for allowing M.L. to conduct the interviews from their facilities during the spring of 2019. Mette Morsing would like to thank the Mistra Foundation for financial support in producing this paper.

Conflicts of Interest: The authors declare that they have no known competing financial interests or personal relationships that could have appeared to influence the work reported in this paper.

\footnotetext{
Abbreviations

International Renewable Energy Agency = IRENA; Multinational Enterprises (MNE); Small and Medium-sized Enterprises (SME); Sustainable Development Goals = SDGs; Sustainable Development Goal number 7 = SDG7; United Nations Global Compact $=$ UNGC.
}

\section{References}

1. Corporate Knights. 2020 Global 100 Most Sustainable Companies. Available online: https://www.corporateknights.com/reports/ 2020-global-100/2020-global-100-ranking-15795648/ (accessed on 8 February 2020).

2. CSRHub. Csrhub: Sustainability Management Tools. Available online: https:/ /www.csrhub.com/ (accessed on 26 March 2020).

3. United Nations. Sustainable Development Goal 7. Available online: https://sustainabledevelopment.un.org/sdg7 (accessed on 15 July 2019).

4. Alloisio, I. Sdg 7 as an Enabling Factor for Sustainable Development; Florence School of Regulation: New York, NY, USA, 2018.

5. Laudal, T. Drivers and barriers of csr and the size and internationalization of firms. Soc. Responsib. J. 2011, 7, 234-256. [CrossRef] 
6. Sweeney, L. Corporate social responsibility in ireland: Barriers and opportunities experienced by smes when undertaking csr. Corp. Gov. 2007, 7, 516-523. [CrossRef]

7. Alotaibi, A.; Edum-Fotwe, F.; Price, A.D. Critical barriers to social responsibility implementation within mega-construction projects: The case of the kingdom of saudi arabia. Sustainability 2019, 11, 1755. [CrossRef]

8. Duarte, F.P.; Rahman, S. Perceptions of corporate social responsibility by bangladeshi managers: An exploratory study. Int. Rev. Bus. Res. Pap. 2010, 6, 119-136.

9. Arevalo, J.A.; Aravind, D. Corporate social responsibility practices in india: Approach, drivers, and barriers. Corp. Gov. 2011, 11, 399-414. [CrossRef]

10. Yuen, K.F.; Lim, J.M. Barriers to the implementation of strategic corporate social responsibility in shipping. Asian J. Shipp. Logist. 2016, 32, 49-57. [CrossRef]

11. Shen, L.; Govindan, K.; Shankar, M. Evaluation of barriers of corporate social responsibility using an analytical hierarchy process under a fuzzy environment-A textile case. Sustainability 2015, 7, 3493-3514. [CrossRef]

12. Stojanovic, A.; Milosevic, I.; Arsic, S.; Urosevic, S.; Mihaljovic, I. Corporate social responsibility as a determinant of employee loyalty and business performance. J. Compet. 2020, 12, 149-166. [CrossRef]

13. Agudo-Valiente, J.M.; Garcés-Ayerbe, C.; Salvador-Figueras, M. Corporate social responsibility drivers and barriers according to managers' perception; evidence from spanish firms. Sustainability 2017, 9, 1821. [CrossRef]

14. Skouloudis, A.; Evangelinos, K.; Nikolaou, I.; Filho, W.L. An overview of corporate social responsibility in greece: Perceptions, developments and barriers to overcome. Bus. Ethics Eur. Rev. 2011, 20, 205-226. [CrossRef]

15. Barrena-Martinez, J.; López-Fernández, M.; Romero-Fernandez, P.M. Drivers and barriers in socially responsible human resource management. Sustainability 2018, 10, 1532. [CrossRef]

16. Garavan, T.N.; Heraty, N.; Rock, A.; Dalton, E. Conceptualizing the behavioral barriers to csr and cs in organizations: A typology of hrd interventions. Adv. Dev. Hum. Resour. 2010, 12, 587-613. [CrossRef]

17. Aslani, A.; Naaranoja, M.; Wong, K.-F.V. Strategic analysis of diffusion of renewable energy in the nordic countries. Renew. Sust. Energ. Rev. 2013, 22, 497-505. [CrossRef]

18. Nordic Energy Research. Tracking Nordic Clean Energy Progress 2020; Nordic Energy Research: Oslo, Norway, 2020.

19. Nordic West Office. Stronger Together: The Future of the Nordic Energy Markets; Nordic West Office: Helsinki, Finland, 2019.

20. IEA. Nordic Energy Technology Perspectives: Pathways to a Carbon Neutral Energy Future; Nordic Energy Research and International Energy Agency: Paris, France, 2013.

21. Nordic Council of Ministers. Nordic Leaders Pledge Most Sustainable Region by 2030. Available online: https://www.norden. org/en/news/nordic-leaders-pledge-most-sustainable-region-2030 (accessed on 13 February 2021).

22. Norden. The Road Towards Carbon Neutrality in the Different Nordic Countries; Nordic Council of Ministers: Oslo, Norway, 2020.

23. Latapí Agudelo, M.A.; Johannsdottir, L.; Davidsdottir, B. Drivers that motivate energy companies to be responsible. A systematic literature review of corporate social responsibility in the energy sector. J. Clean. Prod. 2020, 247, 119094. [CrossRef]

24. Ditlev-Simonsen, C. Csr and employee motivation. In Csr and Beyond-A Nordic Perspective; Midtunn, A., Ed.; Cappelen Damm AS: Oslo, Norway, 2013; pp. 117-134.

25. Johannsdottir, L.; Olafsson, S.; Davidsdottir, B. Insurance perspective on talent management and corporate social responsibility: A case study of nordic insurers. J. Mgmt. Sustain. 2014, 4, 163. [CrossRef]

26. Carroll, A.B. A History of Corporate Social Responsibility: Concepts and Practices. In The Oxford Handbook of Corporate Social Responsibility; Andrew Crane, A.M., Dirk, M., Jeremy, M., Donald, S., Eds.; Oxford University Press: New York, NY, USA, 2008; pp. 19-46.

27. Latapí Agudelo, M.A.; Johannsdottir, L.; Davidsdottir, B. A literature review of the history and evolution of corporate social responsibility. Int. J. Corp Soc. Responsib. 2019, 4, 1-23.

28. Carroll, A.B. Corporate social responsibility: Evolution of a definitional construct. Bus. Soc. 1999, 38, 268-295. [CrossRef]

29. Dahlsrud, A. How corporate social responsibility is defined: An analysis of 37 definitions. Corp. Soc. Responsib. Environ. Manag. 2008, 15, 1-13. [CrossRef]

30. European Commission. Corporate Social Responsibility: A New Definition, a New Agenda for Action; European Commission: Brussels, Belgium, 2011.

31. Friedman, M. The social responsibility of business is to increase its profits. The New York Times Magazine, 13 September $1970 ;$ p. 17.

32. Friedman, A.L.; Miles, S. Developing stakeholder theory. J. Manag. Stud. 2002, 39, 1-21. [CrossRef]

33. Freeman, R.E. A stakeholder theory of the modern corporation. Perspect. Bus. Ethics 2001, 3, 144.

34. European Commission. Eu Multi Stakeholder Forum on Corporate Social Responsibility; Ares(2015)580495; European Commission: Brussels, Belgium, 2015.

35. Tempels, T.; Blok, V.; Verweij, M. Understanding political responsibility in corporate citizenship: Towards a shared responsibility for the common good. J. Glob. Ethics 2017, 13, 90-108. [CrossRef]

36. Carroll, A.B. The four faces of corporate citizenship. Bus. Soc. Rev. 1998, 100, 1-7. [CrossRef]

37. Van Marrewijk, M. Concepts and definitions of csr and corporate sustainability: Between agency and communion. J. Bus. Ethics 2003, 44, 95-105. [CrossRef]

38. Schrippe, P.; Ribeiro, J.L.D. Preponderant criteria for the definition of corporate sustainability based on brazilian sustainable companies. J. Clean. Prod. 2019, 209, 10-19. [CrossRef] 
39. Carroll, A.B. Corporate social responsibility: The centerpiece of competing and complementary frameworks. Organ. Dyn. 2015, 44, 87-96. [CrossRef]

40. Arena, M.; Azzone, G.; Mapelli, F. What drives the evolution of corporate social responsibility strategies? An institutional logics perspective. J. Clean. Prod. 2018, 171, 345-355. [CrossRef]

41. Liu, X.; Garcia, P.; Vredenburg, H. Csr adoption strategies of chinese state oil companies: Effects of global competition and cooperation. Soc. Responsib. J. 2014, 10, 38-52. [CrossRef]

42. Trapp, N.L. Corporation as climate ambassador: Transcending business sector boundaries in a swedish csr campaign. Public Relat. Rev. 2012, 38, 458-465. [CrossRef]

43. Wanvik, T.I. Governance transformed into corporate social responsibility (csr): New governance innovations in the canadian oil sands. Extr. Ind. Soc. 2016, 3, 517-526. [CrossRef]

44. Wilson, E. Negotiating uncertainty: Corporate responsibility and greenland's energy future. Energy Res. Soc. Sci. 2016, 16, 69-77. [CrossRef]

45. Böhm, S.; Brei, V.; Dabhi, S. Edf energy's green csr claims examined: The follies of global carbon commodity chains. Glob. Netw. 2015, 15, S87-S107. [CrossRef]

46. Oh, H.; Bae, J.; Kim, S.-j. Can sinful firms benefit from advertising their csr efforts? Adverse effect of advertising sinful firms' csr engagements on firm performance. J. Bus. Ethics 2017, 143, 643-663. [CrossRef]

47. Bhattacharyya, S.S. Chamera hydro-electric power project (chep-1), khairi: Looking beyond the horizon of hydroelectricity and profit, giving new meaning to life. Vision 2007, 11, 79-93. [CrossRef]

48. Bolton, S.C.; Kim, R.C.-H.; O'Gorman, K.D. Corporate social responsibility as a dynamic internal organizational process: A case study. J. Bus. Ethics 2011, 101, 61-74. [CrossRef]

49. Du, S.; Vieira, E.T. Striving for legitimacy through corporate social responsibility: Insights from oil companies. J. Bus. Ethics 2012, 110, 413-427. [CrossRef]

50. Mezher, T.; Tabbara, S.; Al-Hosany, N. An overview of csr in the renewable energy sector: Examples from the masdar initiative in abu dhabi. Manag. Environ. Qual. 2010, 21, 744-760. [CrossRef]

51. Özcüre, G.; Demirkaya, H.; Eryiğit, N. Is it possible to be a sustainable energy company in turkey? A case study of omv's thermal electric power plant in samsun. Soc. Behav. Sci 2015, 181, 97-106. [CrossRef]

52. United Nations. Sustainable Development-Energy. Available online: https://sdgs.un.org/topics/energy (accessed on 12 July 2019).

53. IRENA. A New World: The Geopolitics of the Energy Transformation; IRENA: Abu Dhabi, United Arab Emirates, 2019; ISBN 978-92-9260-097-6.

54. Lozano, R. A holistic perspective on corporate sustainability drivers. Corp. Soc. Responsib. Environ. Manag. 2015, 22, 32-44. [CrossRef]

55. Zhang, Q.; Oo, B.L.; Lim, B.T.H. Drivers, motivations, and barriers to the implementation of corporate social responsibility practices by construction enterprises: A review. J. Clean. Prod. 2019, 210, 563-584. [CrossRef]

56. Reynolds, S.J. Overcoming the psychological barriers of csr. Organ. Dyn. 2019, 100745. [CrossRef]

57. Pinto, L.; Allui, A. Critical drivers and barriers of corporate social responsibility in saudi arabia organizations. J. Asian Financ. Econ. Bus. 2020, 7, 259-268. [CrossRef]

58. Daft, R.L. Organizational Theory and Design; South-Western Cengage Learning: Mason, OH, USA, 2010.

59. Aguinis, H.; Glavas, A. What we know and don't know about corporate social responsibility: A review and research agenda. J. Manag. 2012, 38, 932-968. [CrossRef]

60. Gond, J.-P.; El Akremi, A.; Swaen, V.; Babu, N. The psychological microfoundations of corporate social responsibility: A person-centric systematic review. J. Organ. Behav. 2017, 38, 225-246. [CrossRef]

61. Hafenbrädl, S.; Waeger, D. Ideology and the microfoundations of csr: Why executives believe in the business case for csr and how this affects their csr engagements. Acad. Manag. J. 2017, 60, 1582-1606. [CrossRef]

62. Maak, T.; Pless, N.M.; Voegtlin, C. Business statesman or shareholder advocate? Ceo responsible leadership styles and the micro-foundations of political csr. J. Manag. Stud. 2016, 53, 463-493. [CrossRef]

63. Garcia-Sanchez, I.-M.; Cuadrado-Ballesteros, B.; Sepulveda, C. Does media pressure moderate csr disclosures by external directors? Manag. Decis. 2014, 52, 1014-1045. [CrossRef]

64. Shea, C.T.; Hawn, O.V. Microfoundations of corporate social responsibility and irresponsibility. Acad. Manag. J. 2019, 62, 1609-1642. [CrossRef]

65. Bhattacharya, C.B.; Sen, S.; Korschun, D. Using corporate social responsibility to win the war for talent. MIT Sloan Manag. Rev. Winter 2008 2008, 49, 37-44.

66. Rupp, D.E.; Ganapathi, J.; Aguilera, R.V.; Williams, C.A. Employee reactions to corporate social responsibility: An organizational justice framework. J. Organ. Behav. 2006, 27, 537-543. [CrossRef]

67. Cropanzano, R.; Byrne, Z.S.; Bobocel, D.R.; Rupp, D.E. Moral virtues, fairness heuristics, social entities, and other denizens of organizational justice. J. Vocat. Behav. 2001, 58, 164-209. [CrossRef]

68. Hoffman, A.; Henn, R. Overcoming the social and psychological barriers to green building. Organ. Environ. 2008, 21, 390-419. [CrossRef]

69. Sen, S.; Bhattacharya, C.B.; Korschun, D. The role of corporate social responsibility in strengthening multiple stakeholder relationships: A field experiment. J. Acad. Mark. Sci. 2006, 34, 158-166. [CrossRef] 
70. Faisal, M.N. Analysing the barriers to corporate social responsibility in supply chains: An interpretive structural modelling approach. Int. J. Logist. Res. Appl. 2010, 13, 179-195. [CrossRef]

71. Li, Y.; Barrueta Pinto, M.C.; Diabat, A. Analyzing the critical success factor of csr for the chinese textile industry. J. Clean. Prod. 2020, 260, 120878. [CrossRef]

72. Zou, Z.; Liu, Y.; Ahmad, N.; Sial, M.S.; Badulescu, A.; Zia-Ud-Din, M.; Badulescu, D. What prompts small and medium enterprises to implement csr? A qualitative insight from an emerging economy. Sustainability 2021, 13, 952. [CrossRef]

73. Lu, J.; Ren, L.; Zhang, C.; Liang, M.; Abrhám, J.; Streimikis, J. Assessment of corporate social responsibility performance and state promotion policies: A case study of the baltic states. J. Bus. Econ. Manag. 2020, 21, 1203-1224. [CrossRef]

74. Coady, L.; Lister, J.; Strandberg, C.; Ota, Y. The Role of Corporate Social Responsibility (CSR) in the International Shipping Sector. In The Northern European Symposium on CSR in Shipping; The Northern European Symposium: Copenhagen, Denmark, 2013.

75. Xia, B.; Olanipekun, A.; Chen, Q.; Xie, L.; Liu, Y. Conceptualising the state of the art of corporate social responsibility (csr) in the construction industry and its nexus to sustainable development. J. Clean. Prod. 2018, 195, 340-353. [CrossRef]

76. Husted, B.W.; Allen, D.B. Strategic corporate social responsibility and value creation among large firms: Lessons from the spanish experience. Long Range Plann. 2007, 40, 594-610. [CrossRef]

77. Lin, C.P. Modeling corporate citizenship, organizational trust, and work engagement based on attachment theory. J. Bus. Ethics 2010, 94, 517-531. [CrossRef]

78. Duarte, F. Working with corporate social responsibility in brazilian companies: The role of managers' values in the maintenance of csr cultures. J. Bus. Ethics 2010, 96, 355-368. [CrossRef]

79. Friedland, R.; Alford, R. Bringing Society Back in: Symbols, Practices, and Institutional Contradictions. In The new Institutionalism in Organizational Analysis; Powell, W.W., DiMaggio, P.J., Eds.; University of Chicago Press: Chicago, IL, USA, 1991 ; pp. $232-267$.

80. Scott, W.R. Institutions and Organizations: Ideas and Interests; SAGE Publications: Thousand Oaks, CA, USA, 2008.

81. Fafaliou, I.; Lekakou, M.; Theotokas, I. Is the european shipping industry aware of corporate social responsibility? The case of the greek-owned short sea shipping companies. Mar. Policy 2006, 30, 412-419. [CrossRef]

82. Fifka, M.S.; Pobizhan, M. An institutional approach to corporate social responsibility in russia. J. Clean. Prod. 2014, 82, 192-201. [CrossRef]

83. Greenwood, R.; Suddaby, R. Institutional entrepreneurship in mature fields: The big five accounting firms. Acad. Manag. J. 2006, 49, 27-48. [CrossRef]

84. DiMaggio, P.J.; Powell, W.W. The iron cage revisited: Institutional isomorphism and collective rationality in organizational fields. Am. Sociol. Rev. 1983, 147-160. [CrossRef]

85. Matten, D.; Moon, J. "Implicit" and "explicit" csr: A conceptual framework for a comparative understanding of corporate social responsibility. Acad. Manag. Rev. 2008, 33, 1-12. [CrossRef]

86. Bocken, N.M.P.; Geradts, T.H.J. Barriers and drivers to sustainable business model innovation: Organization design and dynamic capabilities. Long Range Plann. 2019, 53, 101950. [CrossRef]

87. Ahmad, N.; Ullah, Z.; Mahmood, A.; Ariza-Montes, A.; Vega-Muñoz, A.; Han, H.; Scholz, M. Corporate social responsibility at the micro-level as a "new organizational value" for sustainability: Are females more aligned towards it? Int. J. Environ. Res. Public Health 2021, 18, 2165. [CrossRef]

88. Rosenthal, M. Qualitative research methods: Why, when, and how to conduct interviews and focus groups in pharmacy research. Curr. Pharm. Teach. Learn. 2016, 8, 509-516. [CrossRef]

89. Cassell, C. Conducting Research Interviews for Business and Management Students; SAGE Publications: London, UK, 2015.

90. Castleberry, A.; Nolen, A. Thematic analysis of qualitative research data: Is it as easy as it sounds? Curr. Pharm. Teach. Learn. 2018, 10, 807-815. [CrossRef]

91. Stiles, W. Quality-control in qualitative research. Clin. Psychol. Rev. 1993, 13, 593-618. [CrossRef]

92. Schreier, M. Qualitative Content Analysis in Practice; SAGE: London, UK, 2012.

93. Gölgeci, I.; Gligor, D.M.; Tatoglu, E.; Arda, O.A. A relational view of environmental performance: What role do environmental collaboration and cross-functional alignment play? J. Bus. Res. 2019, 96, 35-46. [CrossRef]

94. Vachon, S.; Klassen, R.D. Environmental management and manufacturing performance: The role of collaboration in the supply chain. Int. J. Prod. Econ. 2008, 111, 299-315. [CrossRef]

95. Raman, S. Managing employees perception on organizational practices-A contextual study on retention of indian mining professionals. Sankalpa J. Manag. Res. 2018, 8, 85-93.

96. Crane, A.; Henriques, I.; Husted, B.; Matten, D. What constitutes a theoretical contribution in the business and society field? Bus. Soc. 2016, 55, 783-791. [CrossRef]

97. Reay, T.; Whetten, D. What constitutes a theoretical contribution in family business? Fam. Bus. Rev. 2011, 24, 105-110. [CrossRef]

98. Whetten, D. What constitutes a theoretical contribution? Acad. Manag. Rev. 1989, 14, 490-495. [CrossRef]

99. Meyer, J.W. Globalization: Sources and effects on national states and societies. Int. Sociol. 2000, 15, 233-248. [CrossRef]

100. Meyer, J.W.; Rowan, B. Institutionalized organizations: Formal structure as myth and ceremony. Am. J. Sociol. 1977, 83, 340-363. [CrossRef] 